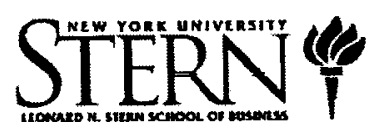

NEW YORK UNIVERSITY
STERN SCHOOL OF BUSINESS
FINANCE DEPARTMENT

Working Paper Series, 1997

The Effects of Bank Mergers and Acquisitions on Small Business Lending

Berger, Allen N., Anthony Saunders, Joseph M. Scalise and Gregory F. Udell

FIN-97-1 

The Effects of Bank Mergers and Acquisitions

on Small Business Lending

\author{
Allen N. Berger \\ Board of Governors of the Federal Reserve System \\ Washington, DC 20551 U.S.A. \\ and \\ Wharton Financial Institutions Center \\ Philadelphia, PA 19104 U.S.A. \\ Anthony Saunders \\ Stern School of Business, New York University \\ New York, NY 10012 U.S.A. \\ Joseph M. Scalise \\ Wharton Financial Institutions Center \\ Philadelphia, PA 19104 U.S.A. \\ Gregory F. Udell \\ Stern School of Business. New York University \\ New York. NY 10012 U.S.A.
}

First circulating draft: January 1997

This draft: March 1997

The opinions expressed do not necessarily reflect those of the Board of Governors or its staff. The authors thank Raghu Rajan for very helpful discussant's comments. Myron Kwast. Phil Strahan. and conference participants at the ASSA meetings and seminar participants at the Federal Reserve Bank of New York for their valuable insights. and Seth Bonime and Margaret Kyle for their valuable rescarch assistance.

Please address correspondence to Allen N. Berger, Mail Stop 153. Federal Reserve Board, 20th and C Sts. NW. Washington. DC 20551. call 202-452-2903. fax 202-452-5295. or email $\mathrm{m} /$ anb00! $a$,frb.gov. 


\title{
The Effects of Bank Mergers and Acquisitions on Small Business Lending
}

\begin{abstract}
We examine the effects of bank M\&As on small business lending. Our methodology permits empirical analysis of the vast majority of U.S. bank M\&As since the late 1970s -- over 6,000 M\&As involving over 10,000 banks (some active banks are counted multiple times). We are the first to decompose the impact of M\&As on small business lending into static effects associated with a simple melding of the antecedent institutions and dynamic effects associated with post-M\&A refocusing of the consolidated institution. We are also the first to estimate the reactions of other banks in local markets to M\&As. We find that the static effects of consolidation which reduce small business lending are mostly offset by the reactions of other banks in the market, and in some cases also by refocusing efforts of the consolidating institutions themselves.
\end{abstract}




\section{Introduction}

The liberalization of geographic restrictions on U.S. banking institutions beginning in the late 1970s has produced a rapid consolidation of the banking industry. From 1979 through 1994, there were over 3,500 mergers in which two or more banks were consolidated under a single charter, as well as more than 5,800 acquisitions in which banks retained their individual charters but became owned by different bank holding companies (BHCs) (see Table 1). As a result of this merger and acquisition (M\&A) activity, the banking industry has been in a state of continuous transition. The consolidation activity has been particularly strong in the first half of the 1991)s -- bank mergers involved about $20 \%$ of industry assets each year, and the holding companies that acquired other banks constituted about another $20 \%$ of the industry in each of these years. This consolidation wave has contributed to a dramatic increase in the average size of banking institutions. The mean size of banks in the U.S. has grown by $88.3 \%$ in real terms from the beginning of the 1980 s to the end of 1995 , while the mean size of complete banking organizations -- the banking assets of independent banks and top-tier bank holding companies -- has grown by $112.0 \%$ over the same time period. Given the importance of the banking industry, it is not surprising that bank M\&A activity has garnered much attention from researchers, policy analysts, and the press.

There are a number of potential benefits from the lifting of geographic barriers to competition in banking and the associated wave of M\&A activity. These include, but are not limited to, increased geographic diversification, improved competition, and the elimination of entrenched inefficient bank managers. What is not so clear is the effect of consolidation on the supply of credit to U.S. businesses. particularly small business borrowers who depend on banks for external credit. According to a recent survey of small businesses. commercial banks are the single most mportant source of credit to small firms (Cole. Wolken. and Woodburn 1996) Prior rescarch has established a fairly strong link between banking institution size and the supply of small business credit. with larger institutions devoting lesser proportions of their assets to small business lending than smaller institutions (e.g. sec Berger. Kashyap. and Scalise 1995. Kecton 1995. Levonian and Soller 1995. Berger and Udell 1996. Peck and Rosengren 1996. Strahan and Weston 1996).

The relationship between bank size and the propensity to lend to small businesses is reflected in Figure I using data for bank balance sheets as of June 1995. As banks get larger, the proportion of assets deroted to small business lending (i.c. domestic C\&I loans to borrowers with bank credit less than \$I million) declines sharply from nearly $9 \%$ of gross total assets (GTA) for small banks to less than $2 \%$ for large 
banks. On the surface. this finding would seem to suggest that as banking assets are shifted on net from smaller to larger institutions through M\&As. the overall supply of bank credit to small businesses may fall substantially. As an extreme upper bound. if the industry were so consolidated that all bank assets were in institutions with assets exceeding $\$ 10$ billion and if the propensities to lend to small business were to remain constant, small business lending would fall by more than half from $\$ 160.4$ billion to $\$ 79.1$ billion (all financial values in real 1994 dollars).

However, this simplistic analysis assumes that lending propensities are static and are determined solely by size of bank. More important, it neglects the fundamental nature of M\&As as dynamic events that may involve significant changes in organizational behavior beyond the simple static aggregation of the merging institutions. Such conclusions also ignore the reactions of other lenders in the same local markets that might pick up any profitable loans that are no longer supplied by the consolidated banking institutions.

In this research. we depart from most of the extant literature by examining the dynamic impact of M\&As. rather than drawing conclusions from a static comparison. We also depart from the entire extant literature -- including the other dynamic studies of bank M\&As on lending -- by recognizing in our analysis that the net impact of an M\&A on small business lending represents the combination of a number of separate and distinct effects, and by measuring the effects of M\&As on lending by other banks in the local market.

We measure four effects of M\&As on small business lending. The static effect is the change in lending propensities which results from simply combining the balance sheets of the participating banks into a larger pro forma institution with combined characteristics. Much like our simple example above, it assumes that the consolidated institution will have the same lending propensities as other institutions of the same size and other characteristics. The remaıning effects are dy namic. the next two of which take into account the fact that merging institutions may change their focus. The restructurine effect identifies the change in lending that follows from decisions to restructure the institution in terms of its size. financial characteristics. and local market competitive position. For example. the consolidated institution may choose to divest some of the combined assets in order to reduce excess capacity in its market, and this reduction in size after the M\&A may alter its propensity to make small business loans. The direct effect of M\&As captures the change in lending propensities that are attributable to a direct change in lending focus above and beyond the changes associated with the static aggregation of banking assets in the M\&A and the restructuring of the size. financial 
characteristics. and competitive position that follow the M\&A. That is, the direct effect is a dynamic effect that captures the difference in lending by the new 'restructured' institution from what another institution of the same size and other characteristics that has not undergone a recent M\&A would be. Finally, the external effect captures the dynamic responses to M\&As of other lenders in the same local markets. This external effect takes into account the possibility that some loans that may have been dropped by the consolidating institutions can create valuable business opportunities for the other banks or nonbank lenders in the same local markets. Thus, even if institutions engaged in M\&As reduce their small business lending substantially, the total supply of these loans in the local market need not decrease substantially because some or all of these loans could be picked up by nearby institutions.

The purpose of this paper is to shed some empirical light on these issues. We measure the static. restructuring, and direct effects of the vast majority of U.S. bank M\&As from the late 1970s to the early 1990 s, a total of over 6.000 M\&As involving over 10,000 banks (many banks are involved in more than one M\&A and are counted multiple times). ${ }^{\prime}$ We also measure the external effects of these M\&As on the lending of all banks in their local markets, whether or not these banks were themselves involved in an M\&A. Because a number of research and policy issues tum on the type of M\&A, we allow for the possibility that these loan supply effects differ for bank mergers versus bank holding company (BHC) acquisitions, for 'mergers of equals' versus other M\&As, for 'family mergers' of banks within holding companies, for out-ofstate acquisitions. etc. We also examine whether the effects of M\&As differ by the relative and absolute sizes of the participants. Importantly, our use of a data set with a relatively long time scries allows us to examine the effects of M\&As three years aftenward to allow enough ume for most of the dynamic effects to occur.

Our results suggest that the static effect tends to substantially reduce small business lending. consistent with prior research Howeier. this effect is laryely if not fully offset by some of our dynamic effects. For bank mergers. the restructuring and direct effects only slightly offset the static effect. but the external effect suggests a strong positive reaction by other banks in the same local markets. For BHC acquisitions. the direct and external effects are each strong enough to ofrset the static effect. These results strongly suggest that a dynamic approach is needed and that inclusion of external effects of M\&As on the

'Excluded were M\&As involving failed banks. which are likely' to have ver' different effects from other M\&As, and observations with incomplete data. 
lending of other local banks may be particularly important. There are also important differences by type of M\&A and by size of participant.

The remainder of the paper is organized as follows. Section II reviews the literature. Section III describes and motivates each of the effects of M\&As on the supply of small business lending, and Section IV formally defines and econometrically models these effects. Section $\mathrm{V}$ presents our empirical analysis of the data on U.S. bank M\&As from the late 1970s through the first part of the 1990s. Section VI concludes.

\section{Review of the Literature}

The bank M\&A literature has covered several topics, including the returns to acquirers and targets (e.g. Cornett and Tehranian 1992, Houston and Ryngaert 1994), the relationship of these returns to measures of performance using accounting ratios (e.g.. Palia 1994. Pilloff 1996), and the cost and profit efficiency consequences of M\&As (e.g., Berger and Humphrey 1992, Akhavein. Berger, and Humphrey 1997). By comparison, the literature measuring the effects of bank M\&As on the supply of credit to small business borrowers is only quite recent and is relatively sparse.

Theory suggests that the larger, more organizationally complex institutions that are created by M\&As may be less inclined than smaller, less complex institutions to lend to small, informationally opaque borrowers -- the borrowers who are most dependent on banks for credit and for whom the bank-borrower relationship is most important. Large institutions may be less inclined to extend loans that demand intimate knowledge of the small business. its owner. and its local market because of Williamson $(1967,1988)$ type organizational diseconomies associated with producing such loans along with other financial service products. These diseconomies might arise because lending to small. informatıonally opaque borrowers and lending to large. informationally transparent borrowers may be distinctly different actwitics that require the use of different technologies and entirely different credit cultures. That is. the polscies and procedures associated with screening and monitoring small. informationally opaque borrowers and transmitting the relevant information within the banking institution may be very different from those associated with providing transaction-driven loans to large. informationally transparent borrowers. ${ }^{2}$ In addition to a financial

'See Ang (1992). Peterson and Rajan (1994.1995), Berger and Udell (1995). Houston and James (1995). and Blackwell and Winters (1997) for more cridence regarding relationship lending to small business borrowers. 
institution's size, its organizational complexity mav also affect its small business lending. Greater organizational complexity -- such as having multiple layers of management or operating in multiple states -may also make it more difficult to provide locally-based small business services in nationally- or internationally-oriented institutions. Together, these arguments suggest that large, complex banking institutions -- whose core business is the provision of capital market financial services -- may have difficulty competing against small, less complex banking institutions in the provision of the latter group's core business product -- loans to small, informationally opaque borrowers. ${ }^{3}$

The new research on the effects of bank M\&As on small business lending has employed two main data sources. The Federal Reserve's Survey of the Terms of Bank Lending to Businesses (STBL) contains detailed contract information on a sample of loans made by about 300 banks per quarter since the late 1970 s, and includes virtually all large banks. The second source is a new section on the June Call Reports on quantities of lending to small borrowers that began in June 1993, so very few time periods are available. Both data sources have sufficient information to estimate the proportions of loans to small business borrowers. defined here and in other studies as borrowers with bank credit of less than \$1 million.

Some of the literature has focused on the association between small business lending and banking institution size and organizational complexity. Berger, Kashyap, and Scalise (1995) and Berger and Udell (1996) using the STBL data. and Keeton (1995), Levonian and Soller (1995), Berger and Udell (1996), Peek and Rosengren (1996), and Strahan and Weston (1996) using the recent June Call Reports all found that small banking institutions tend to invest much higher proportions of their assets in small business loans than large Institutions. In contrast to the unanimity of the effects of institution size. the empirical evidence on the effects of organizational complexity on the supply of small busıness credit are more mixed "Some studics have

${ }^{3}$ Consistent with these arguments. the corporate finance literature has found that large conglomerate nonfinancial firms often engage in asset sales which allow the firms to focus better on their core businesses or specialize in fewer product areas. Such improvements in focus tend to be associated with better operating performance over the three years following the asset sales as well as improvements in stock returns (see John and Orek 1995)

${ }^{4}$ Berger and Udell (1996) found no clear effect of complexity on small business lending using the STBL data. Keeton (1995) analyzed the June 1994 Call Report data on small business lending in the 10th Federal Reserie District and found that banks owned by out-of-state BHCs and with other dimensions of complexity tended to invest smaller proportions of their funds in loans to small business borrowers. In contrast. Whalen (1995) used the June 1993 Call Report information for three states (Illinois. Kentucky. and Montana) and 
concentrated on the liberalization of state geographic banking restrictions, which allows banking institutions to increase in both size and organizational complexity. Berger. Kashyap, and Scalise (1995), using the STBL, found evidence that past relaxation of geographic restrictions has been associated with a reduction in the supply of bank loans to small businesses.

More in line with the analysis in this paper, several studies have pursued a dynamic approach by comparing lending before and after M\&As. Peek and Rosengren $(1996,1997)$, Strahan and Weston (1996,1997), and Craig and Santos (1997) used the recent June Call Report information on small business lending. Peek and Rosengren and Strahan and Weston generally found that M\&As involving small banking institutions increased small business lending. However, their findings differed with regard to the effects of M\&As between large institutions. Peek and Rosengren found decreases in small business lending associated with these M\&As, whereas Strahan and Weston found no clear effect. Craig and Santos (1997) generally found no clear effect of M\&As of either type, with the results depending crucially on the econometric method employed. Keeton (1996.1997) did not use the new small business lending section of the Call Report. but was generally able to isolate small business lending by looking at small banks, which typically cannot make anything but small loans because of legal lending limits and problems of diversification. Keeton found that certain types of acquisitions, particularly purchases by out-of-state institutions, were associated with a reduction in small business lending, generally consistent with Peek and Rosengren's results for M\&As involving large institutions.

Thus. this recent literature as a whole gives a very mixed picture of the effects of bank M\&As on the supply of small business credit. depending upon whether a static versus dynamic approach is pursued. the type of econometric procedure employed. whether bank mergers versus BHC acquisitions are analyed. whether the consolidating instututions are small versus large. and whether they are in the same versus dilferent states This literature also does not reveal how M\&As change the supply of credit -- i.e.. the extent to which various static and dynamic effects may interact to reach a new equilibrium. Importantly: this literature as well leares completely unknown whether any reduction in supply of small business credit by consolidating institutions may be offset by the reactions of other lenders in the same local market that might pick up

found that banks ouned by out-of-state BHCs had equal or greater supply of small business lending than other banks. 
profitable loans dropped by M\&A participants.

In our analysis. we extend the dynamic approach to answer these difficult questions. We decompose the effects of M\&As on small business lending into several static and dynamic effects for the first time in order to identify how M\&As affect the credit supply process. We are also the first to examine the impact of M\&As on lending by other banks in the same local market in order to estimate the total effect of bank M\&As on the supply of credit to small businesses. In addition, we distinguish between the effects of bank mergers and $\mathrm{BHC}$ acquisitions. as well as among several types of each, to account for the possibility that different categories of M\&As may have very different effects on the supply of small business credit. Finally, our use of the long data series from the STBL allows us to analyze a much greater number of M\&A observations than prior studies that used the small business lending section of the Call Report. and allows for a fuller treatment of the dynamic effects of M\&As by using data from a three-year gestation period following the M\&As.

\section{The Four Effects of M\&As on Bank Lending}

Our analysis suggests that the impact of M\&As on bank lending behavior is quite complex, with one static effect and at least three types of dynamic effects. Disentangling these four effects allows us to identify more precisely than the extant literature how M\&As affect small business lending. The static effect is simply the result from the banking institutions combining their pre-M\&A assets into a larger institution with a combined balance sheet and competitive position. The static effect might be expected to result in a decreased supply of small business loans. since (as discussed above) larger banking institutions tend to make fewer

small business loans per dollar of assets. For example, if a bank with $\$ 600$ million in assets merges with a $\$ 400$ million bank. the static effect on small business lending captures the predicted difference in lending between a typical \$I billion bank and the two smaller banks. The \$I billion bank that results from simply adding together the pre-M\&A balance sheets of the merging parties is referred to as the pro forma bank. The static effect also incorporates any impact from combining the financial conditions or other exogenous variables of the two smaller institutions.

The restructuring effect is a dinamic effect of the M\&A duc to a change in focus in which the institution changes its size. financial condition. or competitive position from their pro forma values after consummating an M\&A. In our simple example. the merger of the $\$ 600$ million bank and the $\$ 400$ million bank might eventually result in a consolidated bank of only $\$ 800$ million after the merger. rather than $\$ 1$ 
billion. This could occur, for example, if the purpose of the merger was to reduce excess banking capacity in the local market. This reduction in bank size from $\$ 1$ billion to $\$ 800$ million would likely increase its proportion of assets devoted to small business lending since smaller institutions tend to have higher proportions of these loans.

The consolidated institution's new focus may also be associated with changes in portfolio composition and financial ratios after consolidation because of the inherent diversification benefits of the M\&A, the implementation of new risk-management techniques, changes in operating efficiency, or changes in risk preferences. The change in focus of the consolidated institution may also affect its local market competitive position if. for example. the consolidated institution chooses to shrink after the M\&A and have a smaller market share. Thus, the new institution may restructure itself over time in ways that alter its size, financial condition, or local market competitive position. ${ }^{5}$ In turn, these post-consolidation changes may change the institution's propensity to make small business loans.

The third potentially important factor affecting the merged or acquired bank's supply of business lending is the direct effect. This is the change in lending attributable to a direct refocussing of attention toward or away from small business lending, net of any of the static and restructuring effects already discussed. That is. the direct effect of an M\&A is the difference between a bank's lending after consolidation and the lending of another institution of the same size, financial condition, local market competitive position, and economic environment as the restructured bank that has not undergone an M\&A. In terms of our simple example in which the $\$ 600$ million and $\$ 400$ million banks merge and become an $\$ 800$ million bank after restructuring. the direct effect is how the bank's lending differs from another $\$ 800$ million bank that is the same in eren respect as the restructured bank except that it did not engage in a recent M\&A.

One type of direct effect would occur if the institution changes its lending policies and procedures. perhaps to bring the acquircd part of the institution into accord with the acquirer's lending focus on cither small or large borrowers. Consolidated institutions could also choose to become more or less aggressite in reissuing loans to past customers than other institutions. all else equal. because of the management's

'In some cases. such changes might occur not because of the choice of the banking institution. but because antitrust authorities may require divestiture of some banking operations in overlapping local markets pursuant to an M\&A to keep market concentration from rising excessively. 
philosophy for improving the institution. The institutions that survive mergers may also be more efficient or better diversified than other institutions, and therefore be better equipped to issue more loans. ${ }^{6}$

It may be argued that the restructuring and direct effects of M\&As on lending are not necessarily independent. but rather may be part of the same dynamic refocusing of the consolidated institution. That is, the decision to change institution size, financial condition, and competitive position and the decision to lend to small businesses at a different rate than other institutions of the same characteristics as the restructured institution may be part of the same managerial plan. For example, an institution may restructure to grow larger after a merger because it wishes to switch into larger loans that only more sizable institutions can issue. Nonetheless, we estimate these effects separately, primarily because the evidence cited above suggests that banking institution size is very important in determining the propensity to make small business loans. In estimation, we control for institution size to allow it to have an effect on lending that is independent of the direct effect of M\&As, which in tum necessitates estimating a separate restructuring effect of M\&As that operates through size and similar factors. In any event. the total effect on the lending of consolidating banks from their dynamic refocusing may be determined simply as the sum of the restructuring and direct effects.

The final dynamic effect of M\&As, the external effect. captures the reactions by other lenders in the local market to the change in competitive conditions created by the M\&A. For example, if a consolidated institution reduces its small business lending. this may create opportunities for other local banks to pick up loans with positive net present values. In some cases. loan officers that leave the consolidated institution may start a de novo bank or join other local competitors and keep their connections with small relationship borrowers. Importantly, the external effect does not necessarily act as a partial offset to the change in lending by the consolidating banks. The external effect could more than offset the change in lending by consolidating banks or could eren move in the same direction as these other effects. For example. if some types of M\&As increase the supply of small business loans because a more aggressive competitor has entered the markct. other local banks or nonbank lenders could respond by also increasing their supplies. For estimating the total supply of small business lending. it is just as important to consider this external effect as it is to consider the

"Empirical studies generally do not find that M\&As improve cost efficiency (c.g. Berger and Humphrey. 1992). However. there is evidence that M\&As improve profit efficiency and other measures of performance through enhanced loan diversification (Hawawini and Swary 1990. Benston. Hunter. and Wall 1995. Hughes. Lang. Mester. and Moon 1996. Akhavein. Berger. and Humphrey 1997. Demsetz. and Strahan 1997). 
static, restructuring. and direct effects on the loan supply of the consolidating institutions.

In our empirical analysis below. we measure the effects of M\&As on small business lending by banks in the same local market. Although we exclude nonbank lenders and banks in other local markets from the external effect (because of data and computational limitations). prior analysis found that $84.9 \%$ of small businesses use the services of a commercial bank within 30 miles (Kwast, Starr-McCluer, and Wolken 1997, Table 1), which suggests that we are likely to capture most of any M\&A external effect with our measure.

The measurement of the four effects of M\&As on small business lending requires consideration of the time dimension of the effects. The static effect ends at the time of the M\&A with the combination of the participants into the pro forma institution. By contrast, the dynamic restructuring, direct, and external effects begin to occur after the M\&A and may take several years to complete. For example, it may take time to restructure the consolidated institution's portfolio by divesting assets, or to change its lending focus by promulgating revised lending policies and procedures. In the short term, there may also be temporary disequilibrium due to downsizing, meshing of corporate cultures, or turf battles among managers that draw managerial attention away from the refocusing efforts. Bank managers and consultants often mention three years as the gestation period needed to restructure the institution and change its focus after an M\&A. Some find performance changes as much as five years after M\&As (e.g., Toevs 1992). Research efforts at measuring other performance effects of bank M\&As also have often used a three-year interval (e.g., Comett and Tehranian 1992). The external effect on other banks in the local market is likely to take at least as long as the effects on the institutions involved in the M\&As. so at least three years may be appropriate for measuring the extermal eflect.

The empirical literature discussed above that uses the small business lending section of the Call Report has generally been limited to only one or two years after the M\&As because these data have only recently been collected (since June 1993). It seems likely that these studies may have missed some of the dynamic effects that may take longer to completc. In this study, we use the longer time series available from the STBL data to estimate the three types of dỵnamic effects over a three year horizon. For comparison purposes. we also estimated the dynamic effects for a single year after an M\&A. and we will occasionally

For example. the press reports that it often takes one to three years after an M\&A for the departing loan officers to start a nval de novo bank (e.g.. Epstein 1996). 
reference these estimates.

\section{An Econometric Model of Lending and the Potential Effects of M\&As}

In this section. we present our econometric framework for analyzing the sources of change in loan supply associated with M\&As. We refer to a union in which two or more banks with separate charters were consolidated under a single bank charter as a 'merger,' and denote the remaining bank as a 'survivor' and the bank or banks whose charter(s) disappeared as 'targets.' We refer to a union in which a bank retained its charter, but obtained a different top-tier holding company as an 'acquisition,' the surviving top-tier BHC as the 'acquirer'. and the banks that were directly purchased or were in holding companies that were purchased as the 'acquired. ${ }^{8}$ Whether lending is affected more by mergers or acquisitions depends in large part upon whether effective control of lending decisions most often resides at the bank or holding company level.

The lending equations specify the proportions of a bank's gross total assets (GTA) that are allocated to domestic commercial and industrial (C\&I) loans to different borrower size categories.' Following prior research, we proxy for the size of the borrower by the maximum of I) the size of the loan from the bank, 2) the total commitment under which the loan was drawn from the bank (if any), and 3) the total size of the participation by all banks in a loan participation (if any). This measure is an estimate of the total bank credit available to the borrower. Also consistent with prior research, we define 'small' business borrowers as those with bank credit below $\$ 1$ million. 'medium-sized' borrowers as those with credit between $\$ 1$ million and $\$ 25$ million. 'large' borrowers as those with access to more than $\$ 25$ million in bank credit.

The equations are specified in log-odds logit form. so that the dependent variables are $\ln \left(P_{1} /\left(1-P_{1}\right)\right)$. $i=1.2 .3$. where $\ln$ indicates natural $\log . P_{\text {, is }}$ the proportion of the bank's GTA invested in loans to domestic borrowers in credit categon i $(1=1$ indicales small' borrowers. and so forth $)$ That is. we think of the banking institution as choosing how to allocate its assets among loans to three categories of domestic C\&! borrowers and to other assets. The log-odds ratios are specified as functions of the size. financial condition. and

${ }^{x}$ Some mixed cases are counted as mergers. For example. if Bank $A$ owned by holding company $X$ merges with independent Bank B and only Bank A's charter survives. this is counted as a merger, rather than an acquisition. since the acquired bank's charter did not survive.

${ }^{9}$ Gross total assets include loan loss reseries. We analyze lending in terms of GTA rather than (net) total assets because the value of loans is inclusite of loan loss reserics and because GTA is a superior measure of the size of the bank. 
competitive position of both the bank and its total organization (including assets of other banks held by the top-tier BHC if any), variables indicating recent past M\&A activity, and other variables describing the bank and its environment that might affect lending decisions. The main equations of the model are of the form:

$$
\begin{aligned}
& \ln \left(P_{12} /\left(1-P_{t 1}\right)\right)=f_{i}\left(\text { BANK AND ORG SLZE }_{t-1}, \text { BANK AND ORG FINANCIAL }_{t-1 .}\right. \text {. } \\
& \text { BANK AND ORG COMP POSITION } \text {, }_{t-1} \text {, ORG COMPLEXITY } \text { CO-1 }_{1} \text {, } \\
& \text { PAST M\&A } A_{t-1 . t-2 . t-3,3} \text { MARKET PAST M\&A } A_{t-1, t-2, t-3,3}, \text { TIME }_{t-1,1} \text {, } \\
& \text { ENVIRONMENT } \left._{(-1)}\right)+\epsilon_{i n}, \quad i=1,2,3 \text {. }
\end{aligned}
$$

The definitions and sample means of all the variables in equation (1) are given in Table 2. The data are annual and all of the right-hand-side variables are lagged at least one year relative to the lending proportions on the left-hand-side, eliminating endogenous feedback effects. Thus, lending decisions in one year are functions of the bank and organization size. financial condition, M\&A activity, etc. in the previous year or years. All of the right-hand side variables except for the M\&A variables are stock figures as of year-end t-1, which occur before the lending on the left-hand side, which is a flow that occurs throughout year $t$.

Equations (1) are estimated for all banks in the STBL, which contains data on the characteristics of individual loans that allow us to categorize whether the borrower is small, medium, or large. ${ }^{10}$ In our estimation of the effects of M\&As below, we use predicted values from this equation for essentially all banks involved in M\&As, since the right-hand-side variables are observable for all commercial banks over time from the main body of the Call Report and other regulatory reports.

The BANK SIZE variables include first- and second-order terms in the log of gross total assets. LNGTA and $1 / 2$ LNGTA $=$ as well as dummies for bank size class measured in real 1994 dollars. The size classes are SMALLBANK (GTA < \$100 million). MEDBANK (\$100 million - \$1 billion). LARGEBANK (\$1 billıon - \$10 billion). and HUGEBANK ( $\$ 10$ billion) The dummy for the smallest size class is excluded from the regression specification as the base case. The inclusion of bank size as a continuous variable and as size class dummies allows for both small effects and large changes at the size class level.

The ORG SIZE variables replicate the BANK SIZE variables. except that they are based on

"An exception is that we do not include observations if an M\&A occurs in year $t$ because some of the lending in year $t$ would be made by consolidated and unconsolidated firms. The lending by these banks is then re-included in year $\mathrm{t}+\mathrm{l}$ if no M\&A occurs in that year. 
ORGGTA, which includes all the banking assets in the organization. For banks in BHCs. ORG SLZE is based on all the assets in the banks directly controlled by the top-tier holding company or indirectly controlled through the ownership of lower-tier BHCs. For independent banks or banks in one-bank holding companies. ORG SIZE and BANK SIZE are identical. The inclusion of ORG SIZE allows for the possibility that at least partial control of lending procedures is exercised at the centralized level of the organization.

The BANK AND ORG FINANCIAL variables measure the equity position and condition of the loan portfolio at the bank and organization levels. These variables include the equity/GTA ratio, loan loss reserves/total loans, other rcal estate owned/total loans, nonperforming loans/total loans, and second-order terms in these ratios (i.e., $1 / 2 X^{2}$ ) to allow for nonlinearities. Banks with higher capital ratios and lower problem loan ratios should have a greater supply of credit. all else equal, because of fewer market and regulatory constraints.

The COMP POSITION variables control for the competitive conditions in the local banking markets in which the institution competes. The Herfindahl index and market shares of the bank and organization are measured as weighted averages over all the local markets in which the institution has offices with deposits."

The ORG COMPLEXITY variables control for the managerial structure of the organization, allowing for the possibility that organizational complexity may affect small business lending. We include variables for whether the bank is owned by a BHC, whether there are multiple layers of BHC over the bank, and whether the bank's top-tier BHC is registered with the SEC for public trading. thus adding public shareholders as an additional layer potentially governing the behavior of the bank. We also include an indicator of whether the bank's top-tıer BHC is located in another state. This allows for the possibility that interstate ownership makes it more difficult to make small relatıonship loans or makes it casicr to issue some larger business loans

The PAST M\&A variables account for the presence of M\&A activity in the past three years. and are used for measuring the dinnamic direct effect of M\&As discussed above. We measure the effects of several different țpes of M\&As because they mạ have different potential impacts on small business lending policy and procedures. The variables MERGEDi. $i=1.2 .3$ indicate that the bank is a survivor of one or more bank

\footnotetext{
"Each local market is defined as a Metropolitan Statistical Area (MSA) or non-MSA county. The market structure variables are based on the distribution of deposits from the June Summary of Deposits data. When there was an M\&A between June and December, the COMP POSITION variables were recomputed moving the branches to the surviving bank or acquiring holding company.
} 
mergers i years ago. The variables MERGEDi-EQ indicate whether these were 'mergers of equals,' defined here as when the surviving bank (whose charter is retained) had between $1 / 3$ and 2/3 of the pro forma bank's GTA before the merger. The variables MERGEDi-FAM indicate whether the MERGEDi were family' mergers' of banks that were already in the same top-tier BHC. The ACQUIREDi. $i=1,2,3$ variables indicate that the bank was acquired i years ago, i.e., switched to the control of a different top-tier BHC. Similarly, ACQUIREDi-EQ indicates that the change in control was an 'acquisition of equals' in which the acquiring BHC's GTA before merger was between $1 / 3$ and $2 / 3$ of pro forma holding company's GTA. The variables ACQUIREDi-OUT indicate that the bank was purchased by an out-of-state BHC. These variables should be distinguished from the OUT-OF-STATE variable above. which measured the steady-state effect of interstate ownership. $^{12}$ Finally, the PURCHi, $\mathrm{i}=1,2,3$ indicate that the bank's top-tier BHC purchased other banks in the past three years to incorporate the effects of any drain of managerial attention from the existing affiliates.

The MARKET PAST M\&A variables are the weighted averages of the PAST M\&A variables of all the banks and BHCs in the same local markets (MSA or non-MSA county). For example, MAR-MERGEDi measures the weighted average proportion of deposits in the bank's local market that were in banks that survived mergers i years ago. These variables are used to measure the external effect discussed above -- the effect of M\&As on lending by other banks in the same local market.

The PAST M\&A variables and the MARKET PAST M\&A variables are both also interacted with the BANK SIZE and ORG SIZE variables. Specifically, we interact all past bank merger variables with the log of bank size LNTA. and interact all past acquisition variables with the log of BHC size LNORGTA. These variables allow the effects of M\&As to depend on the size of the institution.

The remaining variables control for differences in the time period and economic environment of the bank. The TIME dummies for every year control for changes in macrocconomic conditions. regulations. and technology over time. The ENVIRONMENT variables include dummies for even state (except the base case of California) to control for differences in demand and supply. conditions and state banking regulations. We also specify. dummies for the bank's primary federal regulator. FED. FDIC. OCC to control for differences in regulatory treatment (OCC excluded as the base case). Finally, we include INMSA. a dummy for whether

\footnotetext{
"The interstate acquisitions have no analogy at the bank level because interstate branching was prohibited over the sample interval.
} 
the bank is headquartered in an MSA, since metropolitan and rural markets differ so greatly.

\section{Measurement of the Static Effect}

To measure the static effect. we simply take the lending predicted by equation (1) for the pro forma bank less the lending predicted by equation (1) for the pre-M\&A banks. This gives the effects of increasing the size of the institution (bank. organization. or both), any change in organizational complexity, local market share, or concentration, and any effects of combining the financial ratios and other conditioning variables of the consolidating parties. The balance sheet and other right-hand-side variables are formed as of year-end $t-1$, which predicts what lending would have been in year $t$.

We illustrate with our simple example of the $\$ 600$ million and $\$ 400$ million banks merging. which we refer to as Banks A and B, respectively. For the purposes of this illustration, we assume that neither bank is in a BHC, so that organization size equals bank size in this example. The pro forma bank has GTA of \$1 billion as of year-end $\mathrm{t}-1$, and the proportion of this GTA predicted to be invested in loans during year $\mathrm{t}$ to borrower size category i, $\mathrm{P}_{1}^{\mathrm{PF}}$, is given by:

$$
\begin{aligned}
& \ln \left(\mathrm{P}_{11}{ }^{\mathrm{PF}} /\left(1-\mathrm{P}_{11}{ }^{\mathrm{PF}}\right)\right)=\mathrm{f}_{\mathrm{i}}\left(\mathrm{BANK} \text { AND ORG SIZE }{ }_{1.1}{ }^{\mathrm{PF}}, \text { BANK AND ORG FINANCLAL }_{t-1}{ }^{\mathrm{PF}}\right. \text {, } \\
& \text { BANK AND ORG COMP POSITION }{ }_{t-1}{ }^{\mathrm{PF}} \text {, ORG COMPLEXITY }{ }_{t-1}{ }^{\mathrm{PF}} \text {. }
\end{aligned}
$$

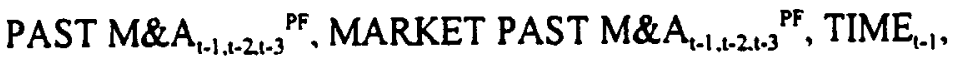

$$
\begin{aligned}
& \text { ENVIRONMENT }_{\text {t.1 }}{ }^{\mathrm{PF}} \text { ) } \quad \mathrm{i}=1,2,3 \text {, }
\end{aligned}
$$

where $f$ indicates that these are predicted values using the estimated parameters from equation (1). The PF superscripts on the right-hand-side variables denote the initial conditions under which the pro forma bank would operate -- bank and organization size of $\$ 1$ billion: financial ratios. past M\&A and market M\&A activit! numbers that are weighted averages of the year-end $t-1$ figures for $A$ (weight $=6$ ) and $B$ (weight $=4)$. and compctitive position. organizational complexity. and entironmental variables that depict the consolidated institution

Again using the estimated parameters from equation (1). the predicted value of proportion of GTA that Bank A would lend to borrower calcgory i during year $t$ if it had not been merged is given by.

$$
\begin{aligned}
& \ln \left(P_{11}{ }^{\lambda} /\left(1-P_{n}{ }^{A}\right)\right)=\Gamma_{1}\left(\text { BANK AND ORG SIZE }_{1.1}{ }^{\wedge} \text {. BANK AND ORG FINANCIAL }{ }_{1-1}{ }^{\wedge}\right. \text {. } \\
& \text { BANK AND ORG COMP POSITION }{ }_{t-1} \text {. ORG COMPLEXITY }_{t-1}{ }^{\wedge} \text {. }
\end{aligned}
$$

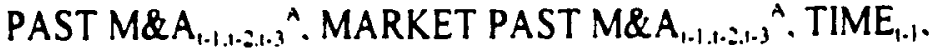

$$
\begin{aligned}
& \text { ENVIRONMENT }{ }_{t .1}{ }^{A} \text { ) } \\
& 1=1.2 .3 \text {. }
\end{aligned}
$$


The predicted proportions for Bank B follow analogously. The estimated static effect on the proportion of GTA lent to borrowers in category $i$ is given by

$$
\text { Static Effect }=\mathrm{P}_{\mathrm{tt}}^{\mathrm{PF}}-.6 \bullet \mathrm{P}_{\mathrm{t}}^{\mathrm{A}}-.4 \bullet \mathrm{P}_{\mathrm{n}}^{\mathrm{B}} \quad \mathrm{i}=1.2 .3 \text {. }
$$

\section{Measurement of the Restructuring Effect}

The restructuring effect measures the change in lending associated with the changes in the pro forma institution's size, financial condition, and competitive position that occur after consummating an M\&A. This is somewhat complicated by the secular change in these variables over time due to changes in macroeconomic conditions, regulations, and technology. We estimate both secular change and the restructuring effect using essentially the same two-step procedure. We estimate the changes in size, condition, and competitive position that are expected to occur over time after the M\&A, and then we plug these changes into equation (1) to obtain the predicted effects of these changes on bank lending.

To estimate the expected changes over time in banking institution size, financial condition, and competitive position. we estimate regression equations with the changes in these factors as the dependent variables. We illustrate this procedure for the change in the log of bank GTA over the $j$ years after $t-1$. The regression for the change in LNGTA from period $t-1$ to $t+j-1, j=1$, is given by:

$$
\begin{aligned}
& \Delta \text { LNGTA }_{t+j-1}=g\left(\text { BANK AND ORG SIZE }_{t-1}, \text { BANK AND ORG FINANCLAL }_{t-1},\right.
\end{aligned}
$$

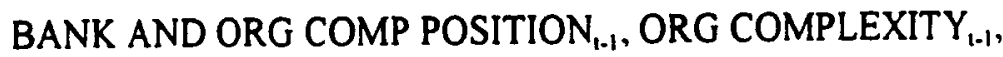

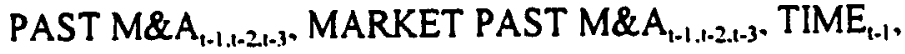

$$
\begin{aligned}
& \text { ENVIRONMENT, } T_{1-1} \text { CURRENT M\&A, } \\
& \text { MARKET CURRENT M\&A } \left.A_{1}\right)+\eta_{\ldots,+1}^{j} \text {; } 1 .
\end{aligned}
$$

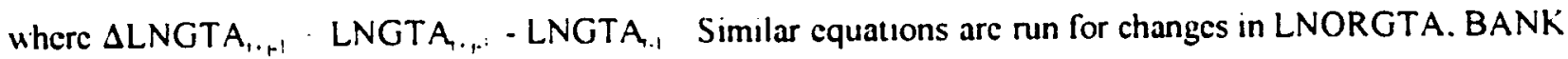
AND ORG FINANCIAL, and COMP POSITION variables The right-hand-side of these equations includes all the variables from equation (1) plus variables for CURRENT M\&A and MARKET CURRENT M\&A for year $t$. These M\&A variables do not create a problem of endogencity. since the current M\&As occur during year $t$ and the dependent variables are measured at the end of year $t$ or later.

For banks involved in M\&As. the data on the right-hand-side of (5) and the LNGTA ${ }_{1-1}$ on the lefthand-side use the pro forma bank. so that we may measure the changes in size. condition. and competitive position relative to the pro forma bank. Equations (5) can be estimated for virtually all observations using 
Call Report data for any year. since data on borrower size are not needed. As discussed above, our main estimates of the dynamic effects of mergers allow for three years of changes after the M\&A, so we will set $j=3$ and estimate the changes in lending in year $t+3$. Since the size, condition, and competitive position variables are all lagged one year in the lending equation (1), we estimate in equation (5) the three-year changes in these variables from year $t-1$ to year $t+2$. Since we also estimate the dynamic effects one year after M\&A for comparison purposes, we also set $j=1$ and estimate equation (5) for the change in variables from $\mathrm{t}-1$ to $\mathrm{t}$.

The secular change in LNGTA for banks involved in M\&As are measured by the predicted values of (5), setting all the $t-1$ values and the PAST M\&A values to those of pro forma bank, and setting the CURRENT M\&A values to zero (as if the bank was not in a current M\&A):

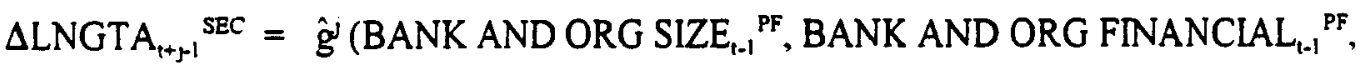

$$
\begin{aligned}
& \text { BANK AND ORG COMP POSITION }{ }_{t-1}{ }^{\mathrm{PF}} \text {, ORG COMPLEXITY }{ }_{t-1}{ }^{\mathrm{PF}} \text {, }
\end{aligned}
$$

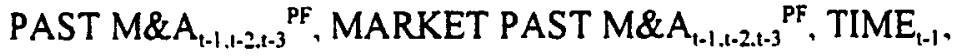

$$
\begin{aligned}
& \text { ENVIRONMENT }_{t-1}^{\mathrm{PF}}, 0 \text {, } \\
& \text { MARKET CURRENT M\&A,). j:I. }
\end{aligned}
$$

where 0 denotes a vector of zeros for the CURRENT M\&A vector. Thus, $\triangle L_{N G T A_{1+-1}}{ }^{\text {SEC }}$ reflects how the pro forma bank's LNGTA would be expected to evolve from period $t-1$ to $t+j-1$, leaving out any effects of the current M\&A other than the static effect that created the pro forma bank. Equations (6) are repeated for the organization size, and the bank and organization financial and competitive position variables.

The predicted lending proportions inclusive of secular change as well as the static effect are given by plugging these predicted changes in sizc. condition. and competitive position into the estimates of equation (1) That is. we add to the pro forma bank the predicted changes in size. condition. and structure and measure the predicted lending in period $\mathrm{i}+\mathrm{J}$.

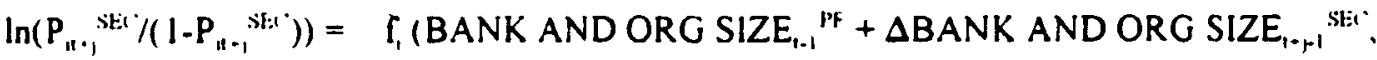

$$
\begin{aligned}
& \text { BANK AND ORG FINANCIAL }{ }_{1.1}^{\text {"r }} \\
& +\triangle \text { BANK AND ORG FINANCIAL }_{t+51} \text { SEl }^{\circ} \text {. } \\
& \text { BANK AND ORG COMP POSITION }{ }_{t-1}{ }^{\mathrm{PF}} \\
& +\triangle \text { BANK AND ORG COMP POSITION, }_{1, .1}^{\text {SEI? }} \text {. }
\end{aligned}
$$

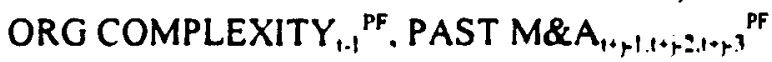

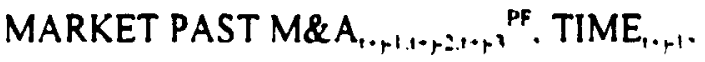




$$
\text { ENVIRONMENT } \left._{t+j-1}{ }^{\mathrm{PF}}\right) .
$$

The estimated secular change in the proportion of GTA lent to borrowers in the ith category $j$ years after the M\&A is simply obtained by subtracting off the pro forma proportion, giving:

$$
\text { Secular change }=P_{i(t+j}{ }^{S E C}-P_{n t}^{P F} . \quad \quad i=1,2,3 ; j=1 .
$$

To estimate the restructuring effect. we calculate the predicted changes in LNGTA and the other variables from equation (6) as above, except that the CURRENT M\&A vector replaces the 0 vector. Thus,

$$
\begin{aligned}
& \triangle \text { LNGTA }_{t+j-1}{ }^{\text {RES }}=\hat{\mathrm{g}}^{\mathrm{J}}\left(\mathrm{BANK}^{\mathrm{B}} \text { AND ORG SIZE }{ }_{t-1}^{\mathrm{PF}} \cdot \text { BANK AND ORG FINANCLAL }_{t-1}{ }^{\mathrm{PF}}\right. \text {, } \\
& \text { BANK AND ORG COMP POSITION }{ }_{t-1}{ }^{\mathrm{PF}} \text {. ORG COMPLEXITY }{ }_{t-1}{ }^{\mathrm{PF}} \text {, } \\
& \text { PAST M\&A } A_{t-1,1-2, t-3}{ }^{\mathrm{PF}}, \text { MARKET PAST M\&A } A_{t-1,1-2, t_{1-3}}^{\mathrm{PF}}, \mathrm{TIME}_{\mathrm{t}-1} \text {, } \\
& \text { ENVIRONMENT }{ }_{t-1}{ }^{\mathrm{PF}}, \mathrm{CURRENT} M \& \mathrm{~A}_{t} \text {, } \\
& \text { MARKET CURRENT M\&A.), } \quad \mathrm{j}=1 \text {. }
\end{aligned}
$$

The predicted lending proportion $\mathrm{P}_{\mathrm{l}+\mathrm{j}}{ }^{\mathrm{RES}}$, which now includes the restructuring effect, again uses the coefficients of the lending equation (1). It is the same as the predicted value from equation (7) except for the adjusted changes in size, condition, and competitive position that embody the effect of the current M\&A:

$$
\begin{aligned}
& \ln \left(\mathrm{P}_{i t+j}{ }^{\text {RES }} /\left(1-\mathrm{P}_{1++j}{ }^{\text {RES }}\right)\right)=\mathfrak{f}_{i}\left(\text { BANK AND ORG SIZE }_{t-1}{ }^{\mathrm{PF}}+\Delta \text { BANK AND ORG SIZE }_{t++1}{ }^{\text {RES }}\right. \text {, } \\
& \text { BANK AND ORG FINANCIAL }{ }_{1-1}{ }^{p F} \\
& +\triangle \text { BANK AND ORG FINANCIAL }_{1++1}{ }^{\text {RES }} \text {. } \\
& \text { BANK AND ORG COMP POSITION }{ }_{1-1}{ }^{\text {PF }} \\
& +\triangle \text { BANK AND ORG COMP POSITION }_{1+-1} \text { RES }
\end{aligned}
$$

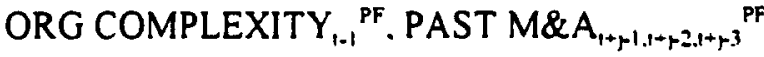

$$
\begin{aligned}
& \text { MARKET PAST M\&A, } A_{1,1,1+1,1, r^{3}} \text {. TIME }
\end{aligned}
$$

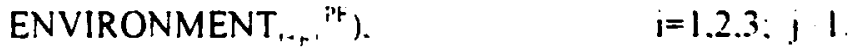

Thus. the estimated restructuring effect on the proportions of GTA lent j years after the M\&A is given by:

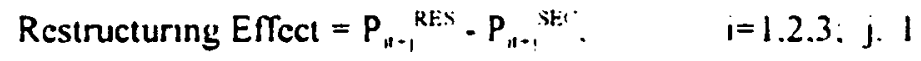

\footnotetext{
"The PAST M\&A and MARKET PAST M\&A vectors in this equation have the PF script, indicating that these variables contain only the M\&A information available as of the time of the pro forma bank. $t-1$. That is. the PAST M\&A $A_{1+, 1, \ldots+2, \ldots+3)}{ }^{P F}$ simply updates the M\&A history of the pro forma bank. moving any M\&As that might have occurred prior to year $t$ to later positions in the vector. excluding any M\&As that might have occurred in $t$ or thereafter. For cxample. when $j=1$ and lending is being predicted for period $t+1$. any $M \& A$ that occurred in period $t-1$ is trealed as occurning 2 periods ago. and any M\&A from 1.2 as occurring 3 periods ago. but no M\&As are registered as occurring I period ago.
} 


\section{Measurement of the Direct Effect}

The direct effect is the additional effect of M\&As on lending after taking into account the changes in size, funancial condition, and competitive position of the consolidating institutions. It is calculated from the parameters of equation (1), using as a starting point the simulated changes in the right-hand side variables from the static and restructuring effects and the secular change. Thus, the estimated proportion of GTA lent to borrowers in the ith category $\mathrm{j}$ years after the M\&A inclusive of all of these factors, including the direct effect, is given by:

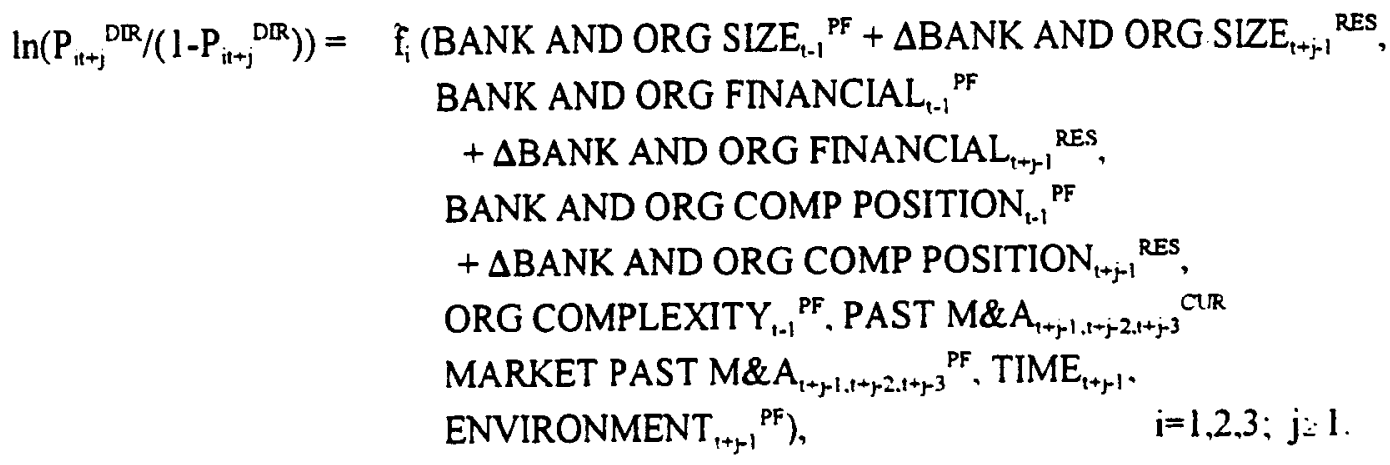

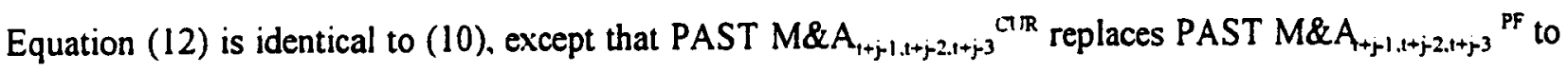
allow for the effects of M\&As in period $t$. The CUR superscript designates that current M\&As in period $t$ are included, but M\&As after period $\mathrm{t}$ are excluded. since they would confound the effects of period $\mathrm{t} M \& A s$.

The estimated direct effect is obtained by subtracting out the other effects:

Direct Effect $=P_{n+1}{ }^{\mathrm{N}}{ }^{\mathrm{N}}-\mathrm{P}_{\mathrm{n}+\mathrm{j}}{ }^{\mathrm{RES}}, \quad \mathrm{i}=1.2 .3 ; \mathrm{j}-1$.

\section{Measurement of the External Effect}

To measure the external effect. we use the MARKET PAST M\&A variables. which to this point have been treated as control variables. For erery bank. we measure the external effect as the impact on their lending of M\&As in their local markets over the past 3 years. If there had been no M\&As in their local markets. the predicted proportion lent to borrowers in size categon. i would be given by the predicted value from equation (1) with the MARKET PAST M\&A variables set to zero:

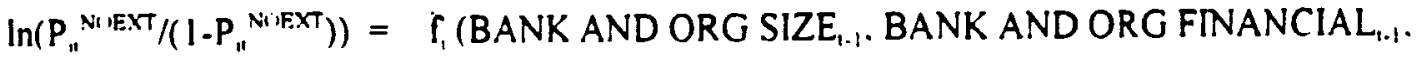

$$
\begin{aligned}
& \text { BANK AND ORG COMP POSITION } \text {, }_{1,1} \text { ORG COMPLEXITY, } Y_{t, 1} \text {. } \\
& \text { PAST M\&A } 1,1,2, \ldots, 0 \text {. TIME } 1.1 \text {. }
\end{aligned}
$$


ENVIRONMENT $_{t-1}{ }^{\mathrm{PF}}$ )

$i=1.2,3$.

The external effect is incorporated by setting the MARKET PAST M\&A variables to their actual values:

$$
\begin{aligned}
& \ln \left(P_{t 1}{ }^{E X T} /\left(1-P_{1 t}{ }^{\text {EXT }}\right)\right)=\quad f_{i}\left(\text { BANK AND ORG SIZE }_{t-1} \text {. BANK AND ORG FINANCLAL } L_{t-1}\right. \text {, } \\
& \text { BANK AND ORG COMP POSITION } \text { CO-1 } \text {, ORG COMPLEXITY }{ }_{t-1} \text {, } \\
& \text { PAST M\&A } A_{t-1.1-2 . t-3} \text {, MARKET PAST M\&A } A_{t-1, t-2, t-3, T_{1 M E}} \text {, } \\
& \text { ENVIRONMENT }_{t-1}{ }^{\text {PF }} \text { ) } \quad \mathrm{i}=1,2,3 \text {. }
\end{aligned}
$$

which is simply the predicted value of equation (1). The difference between these predictions is our estimate of the external effect on the proportion of GTA lent to borrowers in category $i$ in period $t$ :

$$
\text { External Effect }=P_{i t}^{E X T}-P_{t}^{\text {NoEXT. }} \quad i=1.2,3 \text {. }
$$

The external effect is likely to be less accurately measured than the other effects, and so should be looked upon primarily as a qualitative measure to determine how other banks in the market tend to react to M\&As. This is because it would be intractable to form a structural econometric model like that used to measure the static. restructuring. and direct effects. Such a model would require tracing the effect of each individual M\&A to every one of the other banks in the local market, and then map out how each of these other banks might change their size, financial ratios, and competitive positions in response to each M\&A event. Instead, we measure the simple reduced form response of every bank in the nation to the percentage of bank assets in its local market(s) that were involved in M\&As. and recognize the limitations of this measure. It is useful for determining generally whether other local banks may pick up small business loans that might be dropped by banks involved in M\&As or react in other important ways to local M\&As. but should not be viewed as a precise measure of these reactions. Our measure also excludes the reactions of nonbanks and nonlocal lenders. but as noted above. these other sources are much less important than local banks in sericing small businesses.

\section{Empirical Results}

\section{The Static. Restructuring, and Direct Effects}

The top panel of Table 3 shows our analysis of the static. restructuring. and direet effects for mergers. 
and the bottom panel gives the corresponding information for acquisitions. ${ }^{14}$ As discussed above, the dynamic effects shown in the tables reflect three years of change after the M\&As, but we will also occasionally reference results from a single year after M\&A for comparison purposes. We show the effects of M\&As on small, medium. and large business lending, i.e., to domestic business borrowers with bank credit below $\$ 1$ million, $\$ 1$ million to $\$ 25$ million. and over $\$ 25$ million. However, we will focus on the effects on small business lending, where most of the important policy and research questions reside.

All of the results in the paper are for the effects of M\&As on lending during the years $1980-95$, i.e., period $t+j$ after the M\&A ranges from 1980-95. We set $j=3$ for the results shown in the tables, so the M\&As range from 1977-92, three years before the lending data. As shown, we analyze mergers that combine 6.369 banks into 2.508 surviving banks. More than half of the bank charters disappear because there were multiple targets in the same year for some survivor banks. We also analyze 4,146 acquisitions in which a bank has a new top-tier holding company. In many cases, these acquisitions occur simultaneously as one holding company buys another holding company that owns a number of banks. ${ }^{15}$ Note that the 'All Mergers' and 'All Acquisitions' results shown in the table do not force all types or mergers or acquisitions, respectively, to have the same effects on lending. Recall that the model has dummy variables for 'mergers of equals.' 'family mergers,' etc.. as well as interactions of these dummies with the size of the institution. Thus, we allow these different types of M\&As and M\&As of different sized institutions to have different effects on lending. We will investigate some of these differences in subsequent tables. The results in Table 3 should be viewed as weighted average effects over the different types of mergers and acquisitions.

The first column of the top panel of Table 3 shows that the 6.369 merging banks invested $3.702 \%$ of their gross total assets in small business loans the year before the merger. Combining their balance sheets

\footnotetext{
${ }^{14}$ The underlying parameter estimates for equations (1) are shown in Appendix Table Al. We note here that the merger and acquisition variables (which are used to compute the direct effects) are generally statistically significant when craluated in logical groupings. Specifically. F-tests of all PAST M\&A variables and their interactions with the BANK SIZE and ORG SIZE variables, as well as all the subsets referring to each category of M\&As (e.g., 'acquisitions of equals') were performed -- 60 separate F-tests in all. The parameters were jointly significant at the $1 \%$ level in 54 cases. at the $5 \%$ level in 3 cases. and they were not significant in 3 cases.

15For the results one year after M\&As (i.e. $\mathrm{j}=1$ ). we analyze mergers that combine 7.916 banks into 3.106 surviving banks. and 4.714 acquisitions of banks that occur over 1979-94.
} 
into 2.508 pro forma banks yields a static effect on small business lending of -53.3 basis points to $3.169 \%$. using predicted values from lending equation (1). This decline of about $1 / 2$ of one percentage point amounts to about $\$ 25.8$ billion less of small business lending in real 1994 dollars $(-.00533 \cdot \$ 4.852 .4$ billion in GTA). which is about $16 \%$ of total small business lending as of 1995 or almost as much as the total small business lending of all banks with GTA below $\$ 100$ million of $\$ 26.8$ billion in 1995 shown in Figure 1 above. Thus, the static effect reduces small business lending substantially, as the larger consolidated banks are predicted by the model to devote lesser proportions of their assets to small business loans. This confirms the main result of the static literature on the relationship between bank size and small business lending, but does so in a model that takes into account many more factors than are typically employed in these studies.

The secular change shows that the pro forma banks would be predicted to grow in assets and shrink their small business lending proportions in the absence of the dynamic effects of mergers. The data suggest that these banks would have reduced their proportion of small business lending by 87.9 basis points to $2.290 \%$ of GTA, consistent with the strong overall decline in small business lending shown elsewhere (e.g., Berger, Kashyap, and Scalise 1995). ${ }^{16}$

The restructuringeffect is measured as slightly increasing the proportion of GTA invested in small business lending by 6.7 basis points to $2.358 \%$, and slightly increasing the size of merged banks from $\$ 5,217.9$ billion to $\$ 5,249.0$ billion. These data suggest that any restructuring of merged banks in terms of their size. financial condition, or competitive position after M\&As is not important in terms of their small business lending.

The direct effect also appears to increase the proportion of assets invested in small business loans by a ven small amount. 4.9 basis points to $2.416 \%$ of GTA. Thus. by the end of our threc-ycar dynamic period after mergers. the negative static effect of mergers on small busıness lending is only slightly offset by the dynamic restructuring and direct effects. This is illustrated in the final column of Table 3. which shows the sum of static. restructuring. and direct effects of mergers to be -41.6 basis points. almost as large as the static effect alone.

At this point. it is interesting to compare these three-year dynamic effects with the one-year dynamic

${ }^{16}$ This fall in the proportion of assets devoted to small business lending slightly overstates the decline in the quantity of this lending due to secular change. since the $2.290 \%$ has a larger GTA in the denominator. 
effects. The one-year restructuring and direct effects of all mergers were 6.6 basis points and 27.1 basis points, respectively (not shown in tables). Thus, the short-term restructuring effect is small (similar to the longer term effect), but the short-term direct effect is quite large and offsets most of the static effect. This suggests that recently merged banks may look more favorably on small business lending than other banks of the same size and other characteristics or at least are reluctant to cut much of this lending quickly. However, the direct effect becomes much smaller by three years after the merger, so that a substantial reduction in this lending by merged banks eventually does occur. This pattern -- in which most of the reduction in small business lending takes more than a year after merger -- raises questions about recent applications that employed the small business lending section of the Call Report. It may be the case that the data from this new source has simply not been available long enough to measure much of the dynamic effects of M\&As.

The merger results generally show positive effects on lending to medium and large borrowers with bank credit exceeding $\$ 1$ million, especially to borrowers with credit exceeding $\$ 25$ million. The positive static effects were expected based on the literature that found that larger banks tend to lend more to larger borrowers in part because of regulatory and market restrictions on the sizes of loans that smaller banks may issue. The positive static effects are offset in part by negative restructuring and direct effects. ${ }^{17}$

The effects of acquisitions shown on the bottom panel of Table 3 reveal a number of similarities to the effects of mergers. but there are some key differences. Recall that an acquisition differs from a merger in that the acquired bank retains its charter and separate identity, but becomes a subsidiary of a new or different top-tier BHC. For small business lending, the static effects on lending are negative. the restructuring effects are ver. small. and the direct effects are positive. A key difference from the merger results is that the direct effect for acquisitions is relatively large and essentially offsets all of the static effect. so total effects of acquisitions on small business lending are approximately scro.

This result -- that holding company acquisitions do not appear to reduce small business lending by the acquired bank -- suggests that acquisitions may be associated with kecping mostly the same lending

"The positive overall effects on medium and large business lending also support the hypothesis that through consolidation. banks may be better able to preserve their pan of their declining share of the corporate banking market by offering more banking products to companies that have access to the traded securities markets (Berger and Udell 1993. Berger. Kashyap. and Scalise 1995. Boyd and Gertler 1995. and Boyd and Graham 1996). 
policies and procedures and loan officers within the bank. The acquired bank's loan officers may have strong ties to the local community which enable them to continue extending relationship-based loans to small. informationally opaque borrowers. minimizing the impact of the consolidation on small business lending. The choice of a merger, on the other hand, may be more likely to be associated with a strategic decision to integrate the acquired bank more fully into the acquiring organization, rather than maintaining its local identity, making it less inclined to or less able to extend relationship-based small business loans.

Acquisitions may still have important effects on small business lending in the long run, however, if these acquisitions are preludes to 'family mergers' over the next few years. In sume cases, an acquired bank is merged with an existing BHC affiliate some time after the acquisition, which then yields a reduction in small business lending. These family mergers are analyzed separately below. In our data, $41.3 \%$ of all mergers $(1,036 / 2,508)$ are family mergers, and nearly a quarter $(23.7 \%)$ of newly acquired banks engage in family mergers in the 3 years after acquisition. ${ }^{18}$ Importantly, family mergers are likely to increase dramatically in the near future, as relaxation of interstate banking rules under the Riegle-Neal Act of 1994 allows relatively unrestricted family mergers across state lines as of June 1, 1997.

The acquisitions information also suggest more of a shift into medium and large business lending than was the case for mergers. For large loans, the increase in lending is driven by a large positive static effect, suggesting that larger BHCs may help with diversification and allow the acquired banks to initiate more large loans. consistent with the literature cited above. ${ }^{19}$ Similar to the merger data, the acquisitions data suggest some differences in the dynamic effects between one and three years after the M\&A. Specifically, in the shorter term. the shift into medium-sized loans is not yet apparent and the shift into large loans is substantially smaller. again suggesting that the dynamics of M\&As may take setcral years to complete

\section{The Effects by Type of M\&A}

Table 4 summarizes the static. restructuring. and direct effects on small business lending by type of M\&A. We show the total of these three effects on small business lending of mergers of equals. family

\footnotetext{
${ }^{18}$ These figures do not include family mergers which occur in the same year as the acquisition. because as noted above. these mixed cases are counted only as mergers and not as acquisitions in our data set.

"Unlike mergers. acquisitions do not increase legal lending limits. which are set at the level of the bank. not the BHC. Nonetheless. the ability to sell loan participations at low cost within the holding company organization may allow even relatively small banks to initiate loans to large borrowers in some cascs.
} 
mergers. acquisitions of equals, and out-of-state acquisitions. and also include the All Mergers and All Acquisitions categories from Table 3 for comparison. ${ }^{20}$ These results may give insights as to which types of consolidation are likely to produce the most change in lending. As noted above, family mergers and out-ofstate acquisitions are of particular interest because they bear on the likely future effects of interstate banking.

The findings shown in Table 4 suggest that all categories of mergers tend to reduce small business lending by comparable amounts. However, for acquisitions, there appears to be considerable heterogeneity. There may be considerable positive effects on lending for acquisitions of equals and for out-of-state acquisitions, in contrast to the essentially zero effect overall. The excluded residual category (non-equal. in-state acquisitions) obviously has negative effects on small business lending. The finding for out-of-state acquisitions runs contrary to some of the results in the literature cited in Section II above and goes against the conventional wisdom that out-of-state acquirers impose non-local policies and procedures that inhibit relationship-driven small business lending. However, as discussed above, such policies may eventually be imposed if these acquisitions are preludes to family mergers with other banks within the BHC, which are found here to decrease small business lending.

\section{The Effects by Absolute and Relative Size of M\&A Participants}

Table 5 again summarizes the total static, restructuring, and direct effects. now divides it up by the absolute and relative sizes of the M\&A participants. Absolute size may matter, for example, because small and large institutions start from such different small business lending proportions. Relative size may matter. among other reasons. because banks of differing stzes may have more divergent lending focuses.

The top panel of Table 5 suggests that the impact of mergers on small business lending is positive when small and medium size banks (GTA - \$1 billion) merge with cach other. consistent with Peek and Rosengren (1996.1997) and Strahan and Weston (1996.1997). A possible cxplanation of this finding is that these mergers allow small and medium sized banks to increase their business lending as a whole. most of which is restricted to small business lending because of legal lending limits and limited diversification. For cxample. a bank with $\$ 50$ million in assets and a $6 \%$ cquity capital ratio has a legal lending limit to a single

\footnotetext{
"These are not exhaustive categories. nor are they mulually exclusive. For example. in some mergers. the participants are neither of roughly equal size. nor are they in the same top-tier BHC. but in other mergers. the participants may be both roughly equal in size and in the same BHC.
} 
borrower of $\$ 450,000$ (15\% of equity). A merger with a similar bank would double the size of loans and commitments that are permitted. but any extra lending would still generally count as small business lending.

The negative effect on small business lending generally occurs when large survivor banks (GTA $\$ 1$ billion) merge with either large or medium sized target banks. These two large bank merger categories represent about two-thirds of the dollar value of assets merged. The negative effect on small business lending for the larger merger combinations is also consistent with Peek and Rosengren, although Strahan and Weston found no significant effect of large mergers. However, comparisons with prior studies are difficult to make because of our longer sample period, our use of data three years after the mergers, and our structural model that takes into separate account the static. restructuring, and direct effects of M\&As.

The bottom panel of Table 5 suggests that acquisitions of large banking organizations by other large organizations (about two-thirds of assets involved in acquisitions) tends to increase small business lending, but the acquisitions of smaller organizations tends to decrease this type of lending. Thus, our earlier result of essentially no change related to acquisitions masked some significant effects that depend on the sizes of the organizations involved. One potential explanation of this heterogeneity is that the purposes of these acquisitions differ. For instance. the very largest acquisitions may often be for the purpose of market expansion and diversification, and these aggressive acquirers may wish to expand all types of lending. ${ }^{21}$

\section{The External Effect of M\&As}

Table 6 shows the external effect of M\&As on the lending of all banks in the local market in response to the changes in business conditions created by the M\&As. As discussed above, even if institutions engaging

"We also ran a robustness check using the small business lending sections of the June 1993. 1994. and 1995 Call Reports. Which were used by some of the other studies. We re-estımated our small business lending proportion equation (1) using the data for all banks for these three years and then analyzed the findings for the year after the M\&As for the 309 mergers and 293 acquisitions with complete data for 1994 . These findings were compared with our one-ycar-after M\&A results which were based using STBL data in the estimation. The comparison is imperfect because our STBL results are based on a much longer period of estimation (16 years versus 3 ycars) and because we can only replicate the one-year dynamic analysis. in which we have much less confidence than our three-year analysis. The merger results came out quite similar. with the STBL and Call predicting $0.0250 \%$ and $0.0358 \%$ increases in small business loans from 1994 mergers. respectively. This positive finding is consistent between the two data sets for 1994 mergers. but differs from our finding of a negative effect from mergers over the much longer 1979-1994 period. possibly suggesting a change over time. The estimates for 1994 acquisitions differ, with the STBL yielding a positive estimate and the Call yiclding a negative estimate. This may reflect the heterogencity in the acquisition results overall. which vielded essentially a zero effect overall. but strong negative and positive effects for different groups. 
in M\&As reduce their small business lending substantially, the total local supply of these loans need not decrease substantially if there is a strong external effect in which other local banks or nonbanks pick up many of these loans. This external effect is not likely to be important or reliable for loans to larger business borrowers, because these borrowers typically have access to external credit outside the local market. As discussed above, small businesses tend to rely on nearby banks to provide them with financial services, and our analysis of the external effect centers on these local market banks. ${ }^{22}$ The external effect has been neglected in prior empirical analyses of the effects of bank consolidation on small business lending. The first column of Table 6 shows the proportions of GTA devoted to the loan categories assuming no M\&As in the local market, i.e.. by taking the predicted values from equation (1) setting all the MARKET PAST M\&A variables to zero. The remaining columns reflect the effects of setting some of these variables to their actual proportions of local market assets involved in M\&As. The merger results suggest that other banks in the local market do tend to increase their small business lending by 8.5 basis points of their assets, which tends to offset the decline in small business lending by merging banks themselves. The results tend to differ, depending upon the type of merger involved. Similarly, acquisitions tend to increase small business lending by other local banks by 3.9 basis points of GTA, and this effect differs by type of acquisition, with some types having a negative effect on lending by other local banks. The general finding of positive, statistically significant effects of both mergers and acquisitions on small business lending by other local banks suggests that any conclusions about the impacts of banking consolidation that fail to take into account the reaction of other banks may be misleading.

\section{The Total Effects of M\&As on Small Business Lending}

The external effect measured in Table 6 raises the important question of to what extent the estimated reductions in small business lending repored above for merging banks may be offset by increases in small business lending by other local banks. That is. the total supply of small business loans depends upon all the banks in the local market (as well as nonbanks which are not included here). The results given thus far are difficult to compare because the static. restructuring. and direct effects of M\&As are expressed in terms of

\footnotetext{
:Prior research has also found that local market banking concentration affects the rates charged on small business loans (Hannan 1991. Berger and Hannan 1997). This also suggests that altemative lenders are most likely to be local banks.
} 
the assets of the consolidating institutions, whereas the external effect is expressed in terms of the assets of all the banks in the nation. Table 7 puts these effects in comparable terms by multiplying by the appropriate assets and adding up the estimated real dollar magnitudes. The static effect is shown to reduce small business lending by an estimated $\$ 25.8$ billion, which as noted above represents about $16 \%$ of total current small business loans. The positive restructuring and direct effects tend to offset the negative static effect by increasing small business lending by $\$ 3.5$ billion and $\$ 2.6$ billion, respectively, but these effects are relatively weak in economic significance. The estimated external effect of $\$ 48.6$ billion, however, more than offsets the reduction in lending by the merging banks. As noted earlier, we do not believe that the external effect is measured as accurately as the three effects of M\&As on the participaung banks. ${ }^{23}$ Despite this acknowledged imprecision, the strong, positive external effect should be looked upon as evidence in support of the notion that other banks in the local market may respond positively to the change in competitive conditions brought about by a local merger, and offset much if not all of the reduction in supply of these loans by merging banks. For acquisitions, the external effect tends to operate in the same way by increasing small business lending, although there is no reduction in lending by acquired banks to offset because the positive direct effect alone appears to offset the negative static effect. Thus, overall, we cannot reject the notion that the total supply of small business credit associated with M\&As is either unchanged or perhaps positive, despite the finding that mergers tend to reduce such loans by the merging banks.

\section{Vl. Conclusions}

In this study we address an issue that is currently the subject of considerable debate and concern -Is the consolidation of the U.S. banking industry substantially reducing the supply of credit to small businesses" Much has been made of the static cross-sectional relationship between banking instutution size and the proportion of assets devoted to small business lending. However, such analysis ignores the basic nature of M\&As as dỵnamic events which take place for the purpose of changing the focus of the participants. as well as to increase size. It also neglects the reaction of other potential lenders that could offset any: reduction in the supply of small business loans by M\&A participants.

\footnotetext{
"The external and other effects are also slightly noncomparable because the external effect takes into account the entire 3-year merger history of the local market. whereas the other effects trace out the impacts of each M\&A individually. removing the confounding effects of any additional M\&As over the following 3 years.
} 
While several recent papers have viewed this issue in a dynamic context. our study departs significantly from these papers and rest of the extant literature in a number of ways. We examine three distinct effects of M\&As on the small business lending by the participants. The static effect captures the melding of the balance sheets of the consolidating banks into a larger institution, and the restructuring and direct effects capture two sources of change in the focus of the consolidating institutions after the M\&A is completed. Unlike the literature, we also follow the effects of M\&As three years after consolidation to capture more of the dynamic effects. We are also the first to examine the external effect -- the impact of M\&As on small business lending by other banks in the same local market. Without taking into account the reaction of other banks. one cannot draw conclusions about the overall impact of consolidation on the supply of small business credit. Finally, to the best of our knowledge, this is the most exhaustive analysis of the impact of mergers and acquisitions on the lending behavior of banks. Our data and methodology permit us to analyze the effects of the vast majority of M\&As from the late 1970 s through the early 1990 s (over 6,000 M\&As involving over 10.000 banks) on the lending behavior of virtually all U.S. banks.

Our results indicate that the effects of M\&As may be more complex than previous analyses would suggest. While the static aggregation of banking institutions is associated with a considerable negative impact on small business lending. there are significant offsetting effects. In the case of mergers (consolidation of bank charters), the external reaction of other banks in the same local markets appears to offset much if not all of the negative static effect. whereas the dynamic restructuring and direct effects on lending by the consolidating banks themselves appear to be relatively minor. In the case of acquisitions (change of top-tier BHC with charter retained). the negative static effect is offset by both the direct effect of the acquisition and by the external effect Contran to popular belief. acquistions by out-of-state banking organizations do not appear to be associated with a reduction in small business lending by the participating banks.

The absolute and relative sizes of the participating banks also appear to matter. Consistent with carlicr work. we find that small and medium size bank mergers are associated with an increase in small business lending. However. larger bank mergers are in general associated with a decrease in small business Iending. For acquisitions the opposite result obtains -- large holding company acquisitions appear to increase small business lending. whereas smaller acquisitions may tend to decrease this type of lending. However. acquisitions are often preludes to 'family mergers' between banks in the holding company in the following 
few years, which could decrease small business lending. Such family mergers are likely to increase dramatically in the near future. given the relaxation of interstate branching rules.

We caution that our results on past M\&As may not necessarily be accurate predictors of the effects of M\&As in the future. In the last few years. there has been heightened awareness of and concem about the potential problems of small business borrowers by the public and by state and federal legislative and regulatory bodies. The small business lending section of the June Call Reports published since 1993 -- which is itself a byproduct of this heightened awareness -- gives the interested parties information on the small business lending behavior of all U.S. banks on an annual basis. Perhaps in part in reaction to the heightened awareness and scrutiny, some banking institutions seeking to participate in M\&As have made commitments to continue or increase small business lending after consolidation. For example. Wells Fargo pledged to make $\$ 25$ billion in small business loans in the ten years following its consolidation with First Interstate.

Recent changes in the regulatory environment could also change the focus of financial institutions regarding small business lending. For example, family mergers of cross-state affiliates of the same BHC in the future may or may not yield the same effects as past family mergers within a state. Technological changes may affect small business lending in the future as well. As analytical and information technologies such as credit scoring and artificial intelligence decrease the cost of lending to small businesses, the organizational issues that may have discouraged small business lending by larger banking institutions may diminish.

Despite these caveats. however, it seems likely that whatever changes occur in the supply of small business credit by banks participating in M\&As, there may be a significant external effect that will offset much of this change in supply. Most obseriers project that thousands of small. communty banks -- which tend to specialize in small business lending -- will survive consolidation of the banking industr. Nonbank lenders. such as commercial finance companies. are also available to supply credit to small businesses. To the extent that profitable small business Iending opportunities continue to exist. and many small banks and nonbank lenders continuc to exist. it secms likely that the total supply of small business credit will not change drastically in response to the consolidation of the banking industry. 


\section{REFERENCES}

Akhavein, Jalal D.. Allen N. Berger, and David B. Humphrey, 1997, "The Effects of Bank Megamergers on Efficiency and Prices: Evidence from the Profit Function," Review of Industrial Organization 12 (February): 95-139.

Ang, James S.. 1992. "On the Theory of Finance for Privately Held Firms," Journal of Small Business Finance $1,185-203$.

Amel, Dean F., 1993, "State Laws Affecting the Geographic Expansion of Commercial Banks." Board of Governors of the Federal Reserve Working Paper. (September).

Benston, George J., William C. Hunter, and Larry D. Wall, 1995, "Motivations for Bank Mergers and Acquisitions: Enhancing the Deposit Insurance Put Option versus Eamings Diversification," Joumal of Money, Credit, and Banking. 27 (August): 777-88.

Berger, Allen N., and Timothy H. Hannan. 1989. "The Price-Concentration Relationship in Banking," Review of Economics and Statistics, 71 (May): 291-99

Berger, Allen N., and Timothy H. Hannan, 1997, "Using Measures of Firm Efficiency to Distinguish among Alternative Explanations of the Structure-Performance Relationship," Managerial Finance 23: 6-31.

Berger, Allen N., Richard J. Herring. and Giorgio P. Szegö. 1995. "The Role of Capital in Financial Institutions," Joumal of Banking and Finance 19 (June): 393-430.

Berger, Allen N.. and David B. Humphrey. 1988. "Interstate Banking and the Payment System," Lournal of Einancial Services Research 1: 131-45.

Berger, Allen N., and David B. Humphrey, 1992. "Megamergers in Banking and the Use of Cost Efficiency as an Antitrust Defense." Antitrust Bulletin. 37 (Fall): 54 1-600.

Berger, Allen N., Anil K Kashyap, and Joseph M. Scalise, 1995, "The Transformation of the U.S. Banking Industry: What A Long. Strange Trip It's Been." Brookings Papers on Economic Activity (2:1995): 55 218.

Berger. Allen N., and Gregory F. Udell. 1990. "Collateral. Loan Quality, and Bank Risk." Loumal of Monetary Economics 25 (January): $21-42$.

Berger, Allen N and Gregon. F Udell. 1993. "Securitization. Risk. and the Liquidity Problem in Banking." in Structural Change in Banking. edited by Michacl Klausner and Laurence J White. New York" Business One Irwin 227.91

Berger. Allen N., and Gregory F. Udell. 1995. "Relationship Lending and Lines of Credit in Small Firm Finance." Loumal of Business 68 (July) $351-82$.

Berger. Allen N., and Gregon. F. Udell. 1996. "Universal Banking and the Future of Small Business Lending. edited by Anthony Saunders and Ingo Walter. Einancial System Design: The Case for Universal Banking. Burr Ridge. IL. Irwin Publishing: 559-627.

Blackwell. David. and Drew B. Winters. 1997. "Banking Relationships and the Effect of Monitoring on Loan Pricing." Loumal of Financial Research.

Boyd. John H.. and Mark Gcrtcr. 1995. “Arc Banks Dead". Or are the Reports Greatly Exaggerated?" working 


$$
R-2
$$

paper 5045. NBER.

Boyd, John H.. and Stanley L. Graham. 1996. “Consolidation in U.S. Banking: Implications for Efficiency. Competition and Risk," Federal Reserve Bank of Minneapolis working paper (September).

Cole, Rebel A., John D. Wolken. and Louise R. Woodburn, 1996, "Bank and Nonbank Competition for Small Business Credit: Evidence from the 1987 and 1993 National Surveys of Small Business Finances," Eederal Reserve Bulletin, 82:11 (November): 983-95.

Craig, Ben R., and João Cabral dos Santos, 1997, "Banking Consolidation: Impact on Small Business Lending." working paper, Federal Reserve Bank of Cleveland (February).

Demsetz, Rebecca S., and Philip E. Strahan, 1997. "Diversification, Size, and Risk at Bank Holding Companies," Journal of Money, Credit. and Banking. 29.

Epstein. Jonathan D., 1995, "Years of Bank Mergers Trigger a Rise in Start-Ups Looking for Their Niche." American Banker, December 27: 1,6.

Hannan, Timothy H., 1991, "Bank Commercial Loan Markets and the Role of Market Structure: Evidence from Surveys of Commercial Lending," Joumal of Banking and Finance, 15 (February): 133-149.

Hannan, Timothy H., and Stephen A. Rhoades. 1992, "Future U.S. Banking Structure: 1990 to 2010," Antitrust Bulletin, 37 (Fall): 737-98.

Hawawini, Gabriel, and Itzhak Swary, 1990, Mergers and Acquisitions in the U.S. Banking Industry: Evidence from the Capital Markets. Amsterdam, North Holland.

Houston, Joel F., and Christopher M. James, 1995, "Banking Relationships, Financial Constraints and Investment: Are Bank Dependent Borrowers More Financially Constrained," University of Florida Working Paper (December).

Houston, Joel F., and Michael D. Ryngaert, 1994. "The Overall Gains from Large Bank Mergers," Joumal of Banking and Finance. 18, 1155-76.

Hughes. Joseph P.. William Lang. Loretta J. Mester. Choon-Geol Moon. "Efficient Banking Under Interstate Branching." Joumal of Mones: Credil and Banking. 28 (1996).

John. Kose. and Eli Orek. 1945. "Asset Sales and Increase in Focus." Loumal of Financial Economics 37 105. 26

Kecton. William R., 1995. "Multi-Office Bank Lending to Small Businesses: Some New Evidence." Federal Reserve Bank of Kansas City Economic Revieu 80 (2): 45-57.

Keeton. William R.. 1996, "Do Bank Mergers Reduce Lending to Businesses and Farmers? New Evidence from Tenth District States." Federal Reserve Bank of Kansas City Economic Review 81 (3): 63-75.

Keeton. William R.. 1997. "The Effects of Mergers on Farm and Business Lending at Small Banks: New Evidence from Tenth District States." working paper. Federal Reserve Bank of Kansas City (February).

Kwast. Myton L.. Martha Start-McCluer. and John D. Wolken. 1997. "Market Definition and the Analysis of Antitrust in Banking." Antitnusı Bulletia. 42. 


\section{R - 3}

Levonian. Mark, and Jennifer Soller, 1995, "Small Banks. Small Loans, Small Business," Federal Reserve Bank of San Francisco Working Paper, (December).

Palia, Darius. 1994, "Recent Evidence on Bank Mergers." Einancial Markets. Institutions. \& Instruments, 3 (December): 36-59.

Pilloff. Steven J.. 1996, "Performance Changes and Shareholder Wealth Creation Associated with Mergers of Publicly Traded Banking Institutions," Joumal of Money, Credit. and Banking, 28, 294-310.

Peek, Joe, and Eric S. Rosengren, 1996, "Small Business Credit Availability: How Important is Size of Lender?" edited by Anthony Saunders and Ingo Walter, Einancial System Design: The Case for Universal Banking. Burr Ridge, IL, Irwin Publishing.

Peek, Joe, and Eric S. Rosengren. 1997. "Bank Consolidation and Small Business Lending: It`s Not Just Bank Size That Matters." working paper, Federal Reserve Bank of Boston (January).

Petersen, Mitchell A. and Raghuram G. Rajan, 1994, "The Benefits of Firm-Creditor Relationships: Evidence from Small Business Data." Joumal of Finance 49 (March): 3-37.

Petersen, Mitchell A. and Raghuram G. Rajan. 1995, "The Effect of Credit Market Competition on Lending Relationships." Quarterly Joumal of Economics 110 (May): 407-443.

Rhoades, Stephen A., 1992. "Consolidation of the Banking Industry and the Merger Guidelines," Antitnust
Bulletin. 37 (Fall): 689-705.

Strahan. Philip E., and James Weston. 1996, "Small Business Lending and Bank Consolidation: Is There Cause for Concern?" Current Issues in Economics and Finance 2. Federal Reserve Bank of New York (March).

Strahan. Philip E., and James Weston. 1997, "Small Business Lending and the Changing Structure of the Banking Industry," working paper, Federal Reserve Bank of New York (January).

Toevs. Alden. 1992, "Under What Circumstances Do Bank Mergers Improve Efficiency?" Proceedings of a Conference on Bank Stnucture and Competition, Federal Reserve Bank of Chicago, Chicago IL. 602-28.

Williamson. Oliver. 1967. "The Economics of Defense Contracting: Incentives and Performance" in Issues in Defense Economics. ed. R. McKean. New York: Columbia University Press

Williamson. Oliver. 1988. "Corporate Finance and Corporate Governance." LoumaL of Finance 4.3 (July): 567.9$)$ 
Figure 1: Proportions of Gross Total Assets in Domestic C\&I Loans to Borrowers with Bank Credit $<\$ 1$ Million

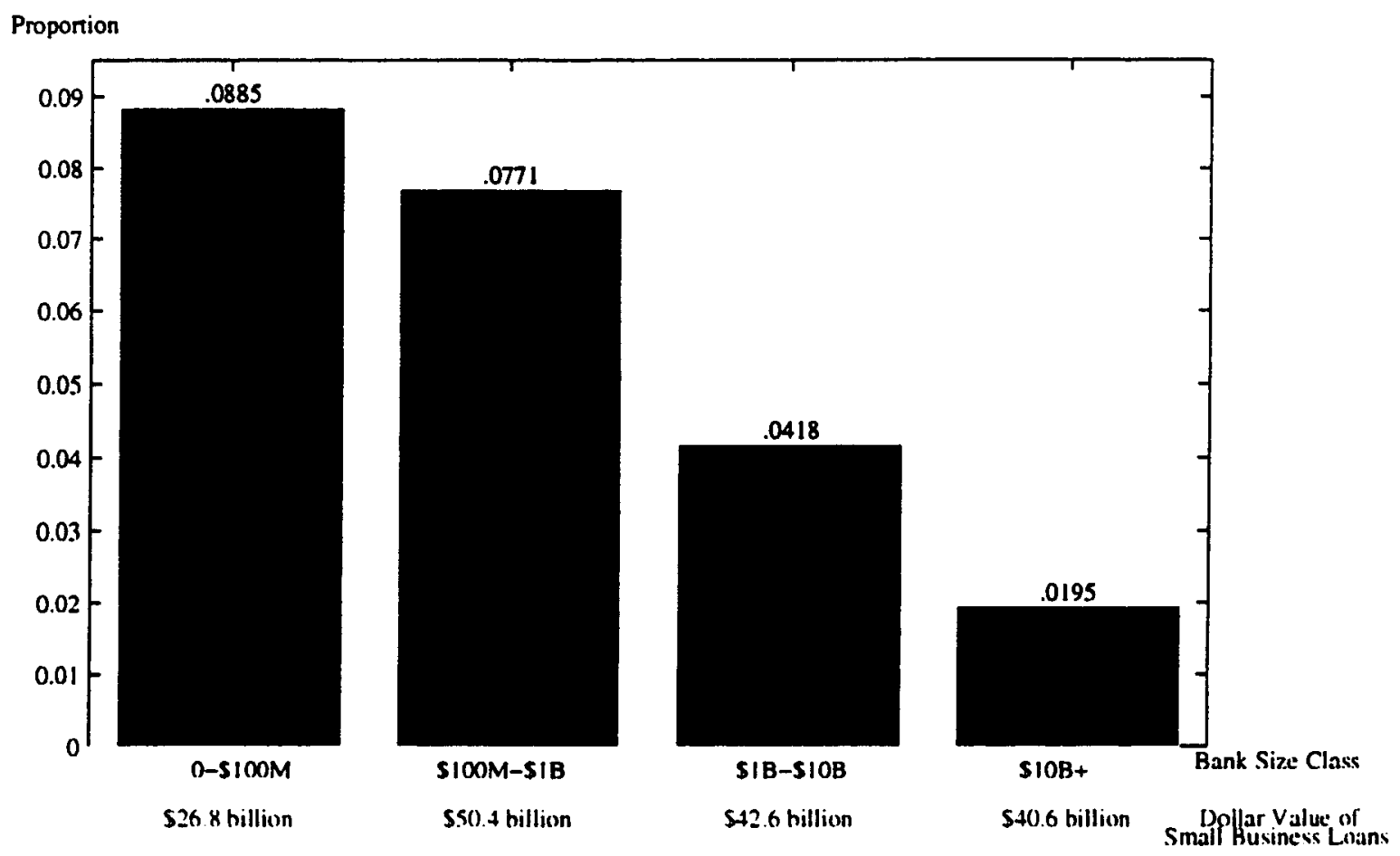

Source Conolidaled Kepon of Condition and Inconk. June 1995

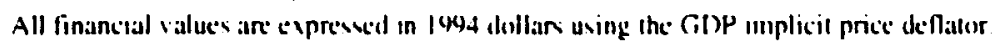




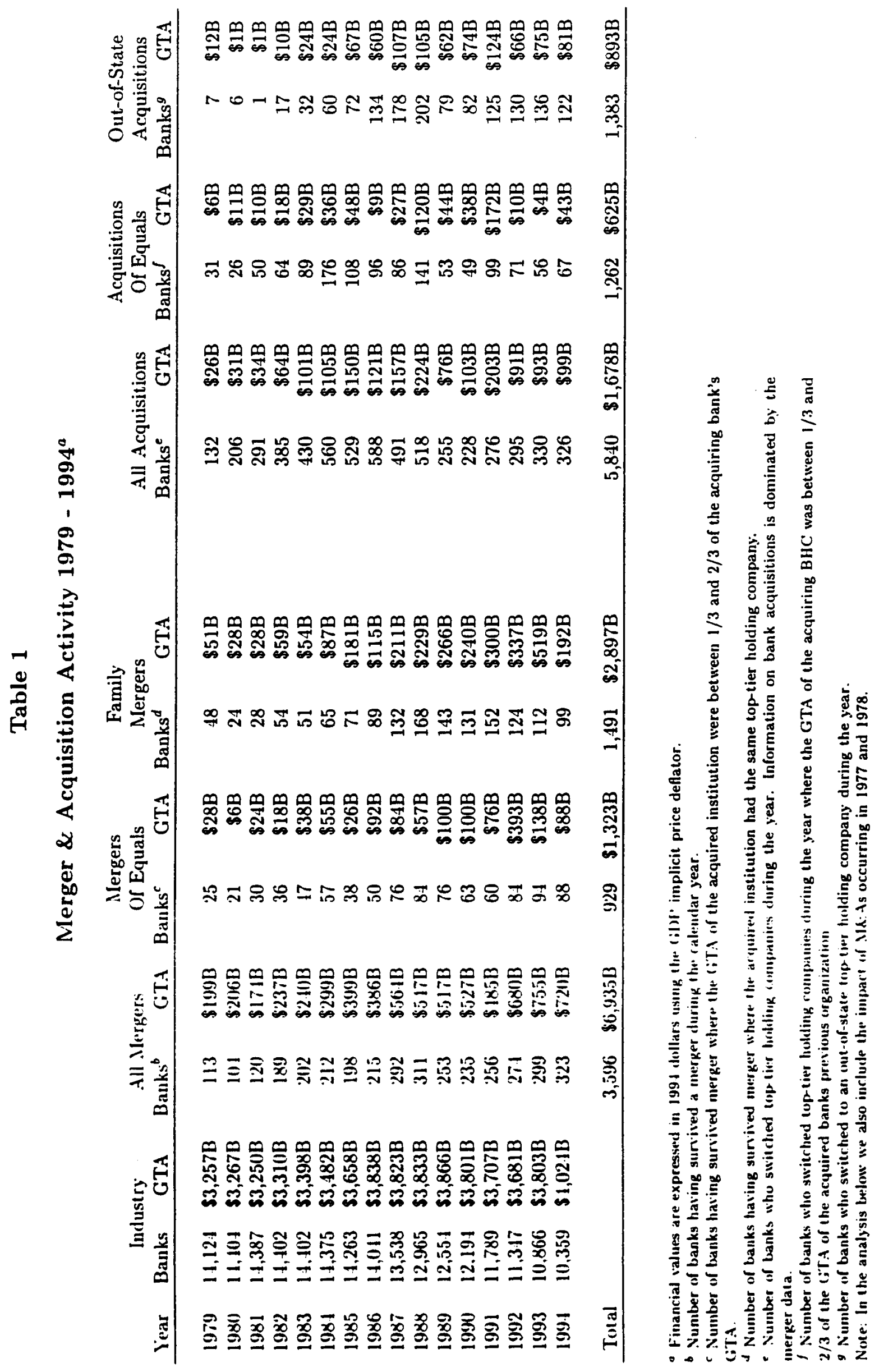


Table 2

Definitions and Sample Means of Variables Employed in the Analysis

(All financial values are in 1000's of constant 1994 dollars.)

Symbel

Definition

Sample Means

STBI Banks All Banks

$P_{1}$

Proportion of gross total assets (GTA) lent to

'small' business borrowers with below $\$ 1$ million

in bank credit.

$P_{2}$

Proportion of GTA lent to 'medium' business

with $\$ 1$ miliion to $\$ 25$ million in bank credit.

Proportion of GTA lent to 'large' business

with over $\$ 25$ million in bank credit.

\section{B. Bank and Organization Size Variableg (BANK AND ORG SIZE)}

LNGTA

Log of bank gross total assets (GTA). Also

13.528

10.958

included as second-order term (1/2 LNGTA $\left.{ }^{2}\right)$.

Interacted with MERGED variables below as well.

SMALLBANR

Dummy variable, equals one if bank has GTA

below $\$ 100$ million. Excluded from the

regressions as the base case.

MEDBANR

Dummy variable, equals one if bank has GTA

of $\$ 100$ million to $\$ 1$ billion.

LARGEBANK

Dummy variable, equals one if bank has GTA of $\$ 1$ billion to $\$ 10$ billion.

over $\$ 10$ bilion.

LNORGGTA, 1/2 LNGORGTA ${ }^{2}$, SMALLORG, MEDORG, LARGEORG, HUGEORG

Same as BANR SIZE variables, except defined over

all the banking assets in the organization

(high holding company).

LNORGGTA is interacted with ACQOIRED variables

below as well.

By construction, BANR SIZE and ORG SIZE variables are identical for independent banks and banks in

one-bank holding companies.

C. Bank and Oraaniration Einancial Variables (BANK AND ORG RTNANCIAW)

EQRAT

Bank equity to GTA ratio. Also included as
as second-order term $\left(1 / 2\right.$ EQRAT $\left.^{2}\right)$.

.071

.087 
Symbe1

LLRRAT

OREORAT

NPFRAT

PFRAT
Definition

Bank loan loss reserve to total loan ratio. Also included as second-order term (1/2 LLRRAT ${ }^{2}$ ).
STBI Banks All Banks

.018

.008

Bank Other Real Estate Owned to total ioan ratiq;
Also included as second-order term ( $1 / 2$ OREORAT).

.030

to total loan ratio.

Also included as second-order term (1/2 NPFRAT ${ }^{2}$ ).

Purchased funds (deposits $\geq \$ 100,000$, foreign

.251

debt, other non-deposit liabilities) to

GTA ratio.

Also included as second-order term (1/2 PFRAT ${ }^{2}$ ).

ORGEQRAT, $1 / 2$ GRGEQRAT ${ }^{2}$, ORGLLRRAT, 1/2 OBGLLRRAT ${ }^{2}$, ORGOREORAT,

$1 / 2$ ORGOREORAT ${ }^{2}$, ORGNPFRAT, 1/2 ORGNPFRAT ${ }^{2}$ ORGORGPFRAT, 1/2 ORGORGPFRAT ${ }^{2}$

Same as BANR FINANCIAL variables, except defined over

all the banking assets in the organization.

D. Local Market Competitive Position Variables (COMP POSITION)

BANKHERF

Herfindahl index of concentration of local

.204

.234

market (MSA or non-MSA county), weighted by

the proportion of the bank's deposits in

each of its markets.

BANRSHARE

Bank's share of market deposits, weighted in

ORGHERF

the same fashion as HERF.

Same as BANRHERF, except defined over all the bank .213

ORGSHARE

same as BANRShaRe, exrept defined over all the hank .204

deposits of the organization.

\section{E. Organizational comolexity Variables (ORG COMPLEXITY)}

BHCOWNED

Dummy variable, equals one if bank is owned

by $a$ bank holding company.

MOLTILEVBLBHC

Dummy variable, equals one if the main 'direct

holder' is not the 'high holder', i.e., that

there are at least two levels of holding company.

POBLICLYTRADED

Dummy

is

if bank's high holder

.606

.222

OOT-OF-STATE

Dummy variable, equals one if bank's high holder

.136

.045 
(Table 2, p. 3)

Symbel

MERGEDi-EQ

MERGEDi-FAM

ACQUIREDi

ACQUIREDI-EQ

ACQUIREDI-OUT

PURCHi
Definition

STBI, Banks

Ald Banks

\section{F. Past Merger and Accuisition Variables (PAST MEA) (Means shown only for the first lag)}

Dummy variable, equals one if bank survived one

or more mergers ( $i . e .$, absorbed the assets of

one or more other banks) i years ago, $i=1,2,3$.

Also interacted with INGTA variable above.

Dummy variable, equals one if bank survived

'mergers of equals' in which it had between

$1 / 3$ and $2 / 3$ of the total pro forma GTA in its

mergers $i$ years ago, $i=1,2,3$.

Also interacted with LNGTA variable above.

Dummy variable, equals one if bank survived one

or more 'family mergers' in which affiliates

of the same high holding company were combined

$i$ years ago, $i=1,2,3$.

Also interacted with LNGTA variable above.

Dummy variable, equals one if bank was acquired

(i.e., changed high holder) $i$ years ago, $i=1,2,3$.

Also interacted with LNORGGTA variable above.

Dummy variable, equals one if bank was acquired

and the acquiring high holder had between $1 / 3$

and $2 / 3$ of the total pro forma organization's GTA

before acquisition $i$ years ago, $i=1,2,3$.

Also interacted with LNORGGTA variable above.

Dummy variable, equals one if bank was acquired

by a high holder located in another state $i$

years ago, $i=1,2,3$.

Also interacted with LNORGGTA variable above.

Dummy variable, equals one if bank's high holder acquired other banks (i.e., banks other than this bank) i years ago, $i=1,2,3$.

Also interacted with LNORGGTA variable above.

F. Market Past Merger and Acouisition Variables (MARKET PAST MEA)

MAR-MERGEDi， MAR-MERGEDi-EQ， MAR-MERGEDi-FAM，MAR-ACQOIREDi， MAR-ACQOIREDI-EQ, MAR-ACQOIREDI-OOT, MAR-PURCHI

Weighted average proportions of PAST M\&A variables of all the banks in the same local markets (MSA or nOn-MSA county). MARMERGED1, MAR-MERGED1-EQ, and MAR-MERGED1-EAM are also interacted with LNGTA, and MARACQOIRED1, MAR-ACQUIREDI-EQ, MAR-ACQOIRED1OUT, and MAR-PORCH1 are also interacted with LNORGGTA. 


\section{G. Time Variables (TIME)}

YEART

Dummy variables, equal one if the lending takes

place in year $t, t=1980, \ldots, 1995$. All year

dummies are included, and no intercept is

specified in the equation.

\section{H. Environmental Variables (ENVIRONMENT)}

INMSA

Dummy variable, equals one if the bank is in i

STATES Metropolitan Statistical Area.

Dummy variable, equals one if the bank is in State $s$, $s=1, \ldots, 50$ to cover all U.S. states and the District of Columbia except for California, which is excluded as the base case.

FED

Dummy, equals one if the bank's primary federal

FDIC regulator is the Federal Reserve.

OCC

Dummy, equals one if the bank's primary federal regulator is the FDIC.

Banks regulated by the occ constitute the base case.

Dummy, equals one if the bank's primary federal regulator is the OCC. Excluded from the regressions as the base case.

Data Sources: Federal Reserve Survey of Terms of Bank Lending to Business Consolidated Report of Condition and Income for Banks (Schedule RC) consolidated Report of Condition and Income for Bank Holding Companies (Schedule Y9-C)

FDIC Summary of Deposits National Information Center Entity Structure Data File

${ }^{1}$ The lending proportions hy horrower size category, $P_{1}, P_{2}$, and $P_{3}$, can only be observed over time for STBL banks, and so only these banks were included in the estimation of equation (1) although the other equations use all banks). Of the 5,351 annual bank observarions available, 853 were not used in equation (1) because of M\&A activity in the same year. The remaining 4,500 were used in the $P_{1}$ and $P_{2}$ versions of equation $(1)$. The $P_{3}$ version eliminated observations in which either the bank or organization had less than $\$ 100 \mathrm{M}$ in GTA, leaving 3,232 observations. For this regression we also deleted the MEDBANK and MEDORG variables and treated medium size as the base case in place of small size. The reason for this treatment is that small banks almost all have either zero or very small proportions of loans to borrowers with over credit over $\$ 25 \mathrm{milli}$. which would make the intercept in this equation (for small banks in small organizations being the base case) essentially equal to minus infinity, which would creace obvious estimation problems. 


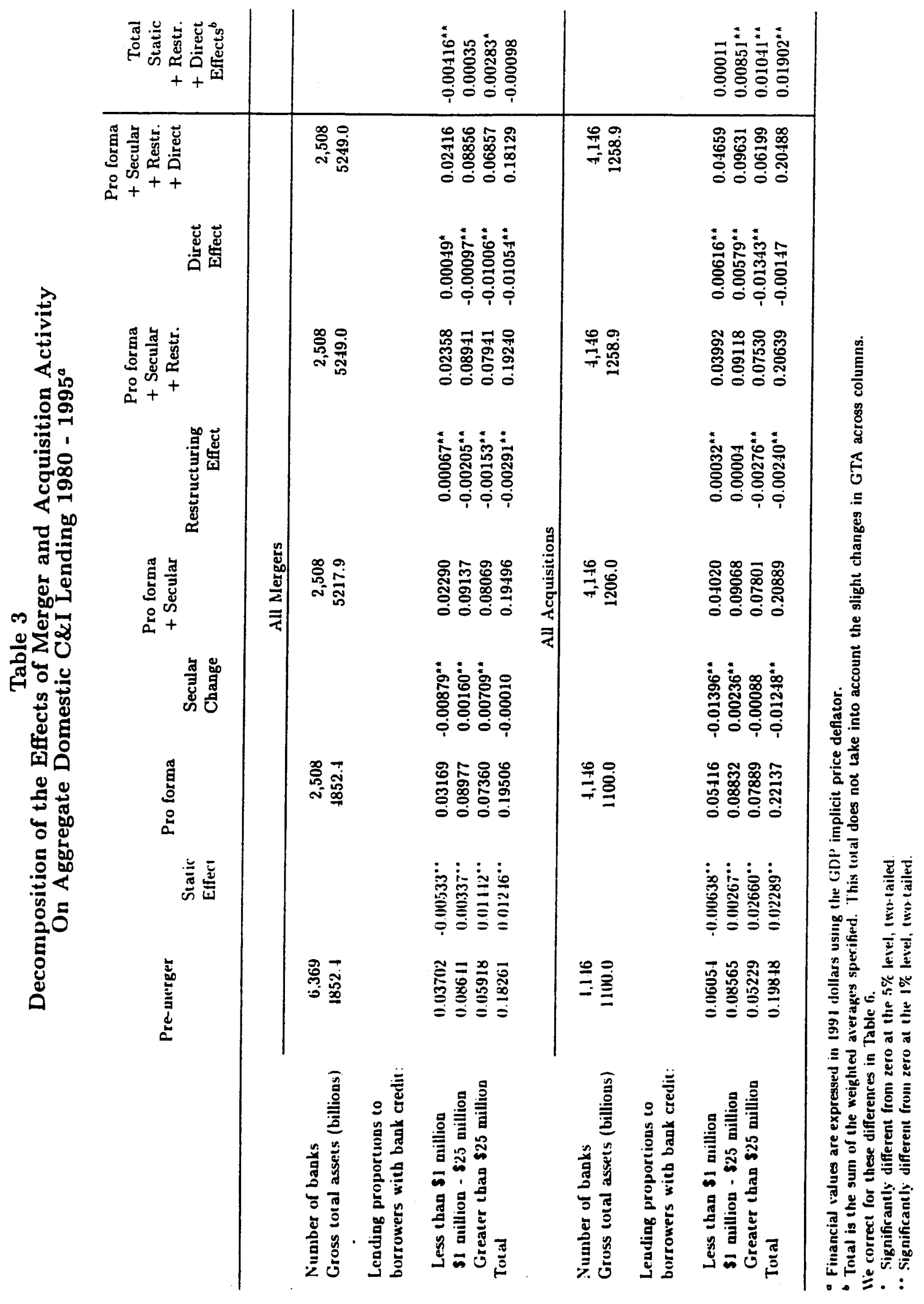




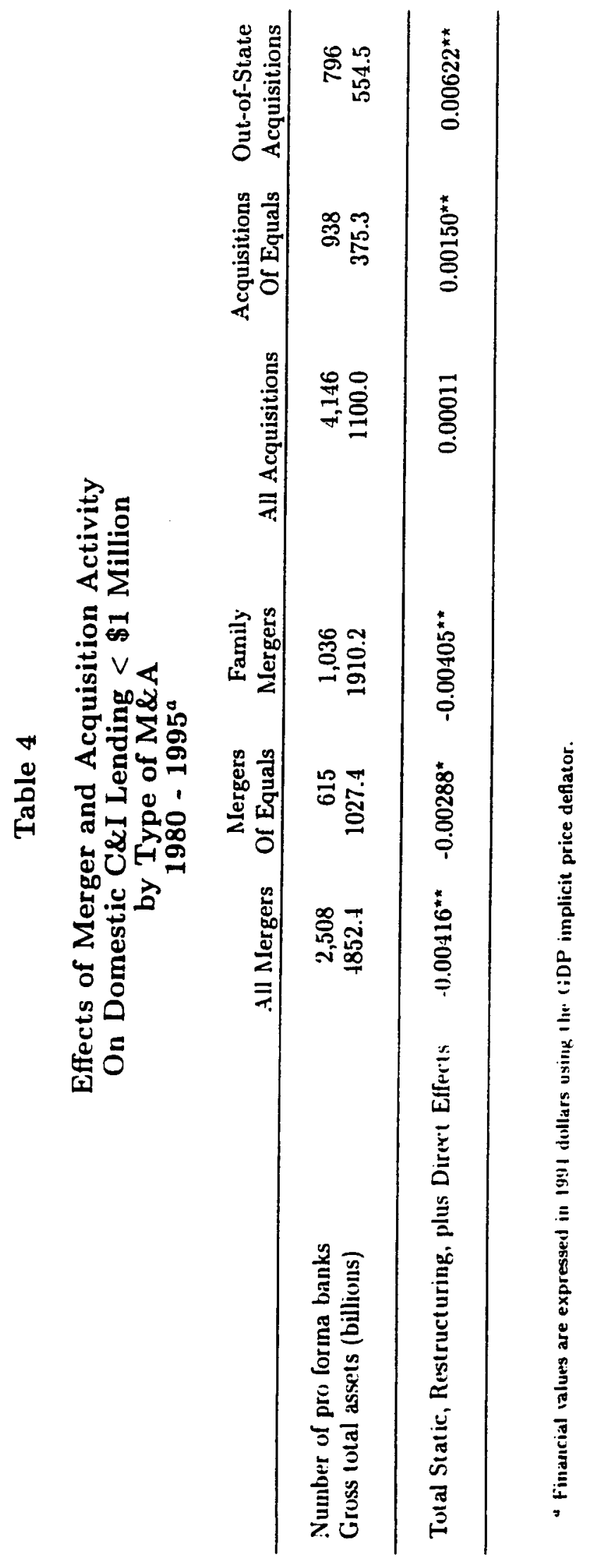




\section{Table 5}

\section{Effects of Merger and Acquisition Activity \\ On Domestic C\&I Lending < $\$ 1$ Million \\ by Absolute and Relative Size of Participants \\ $1980-$ 1995 $^{a}$}

\begin{tabular}{|c|c|c|c|}
\hline \multirow[b]{2}{*}{ Size of Survivor } & \multicolumn{3}{|c|}{$\begin{array}{c}\text { Mergers } \\
\text { Size of Target }\end{array}$} \\
\hline & GTA $<\begin{array}{r}\text { Snnall } \\
100 \mathrm{M}\end{array}$ & $\begin{array}{r}\text { Medium } \\
\text { GTA } \$ 100 \mathrm{M}-\$ 1 \mathrm{~B}\end{array}$ & $\begin{array}{r}\text { Large } \\
\text { GTA } \geq \$ 1 B\end{array}$ \\
\hline $\begin{array}{l}\text { Small (GTA }<\$ 100 \mathrm{M}) \\
\text { Number of pro forma banks } \\
\text { Gross total assets (billions) } \\
\text { Total Static, Restructuring, plus Direct Effects }\end{array}$ & $\begin{array}{c}689 \\
55.6 \\
0.06210^{\star *}\end{array}$ & & \\
\hline $\begin{array}{l}\text { Medium (GTA } \$ 100 \mathrm{M}-\$ 1 \mathrm{~B} \text { ) } \\
\text { Number of pro forma banks } \\
\text { Gross total assets (billions) } \\
\text { Total Static, Restructuring, plus Direct Effects }\end{array}$ & $\begin{array}{r}589 \\
185.6 \\
0.01318^{\star *}\end{array}$ & $\begin{array}{r}293 \\
180.8 \\
0.01286^{\star \star *}\end{array}$ & \\
\hline $\begin{array}{l}\text { Large (GTA } \geq \$ 1 \text { B) } \\
\text { Number of pro forma banks } \\
\text { Gross total assets (billions) } \\
\text { Total Static, Restructuring, plus Direct Effects }\end{array}$ & $\begin{array}{r}122 \\
579.9 \\
0.00139\end{array}$ & $\begin{array}{r}192 \\
932.7 \\
-0.00449^{*}\end{array}$ & $\begin{array}{r}83 \\
1147.8 \\
-0.01046^{* *}\end{array}$ \\
\hline
\end{tabular}

\section{Acquisitions}

Size of Acquirer Organization

$\begin{array}{ccc}\text { Size of Acquired Organization } & \text { Medium } & \text { Large } \\ \text { Small } & \text { Mrg } & \text { ORGTA } \geq \$ 1 B\end{array}$

Snall (ORGGTA < \$100M)

Nunber of acquired banks

Gross total assets (billions)

Total Static, Restructuring, plus Direct Efferts

721

21.7

$-0.01149^{* *}$

Merlium (ORGGTA \$100M-\$1B)

Sumber of acrumired banks

Gross total assets (billiogs)

Total Static, Restructuriug, plus Dirent Efferts

9.18

H.1 66.2

Large (ORGGTA $\geq$ \$1B)

Number of arquired banks

Gross cotal asspets (billions)

Total Static. Restructuring, plus Direct. Efferts
472

28.9

0.011155
711

152.3

$-0.00619^{\circ}$
634

603.1

\footnotetext{
- Finanrial values are expressert in 199.1 dollars using the (iI)t' implicit price deftator.
} 


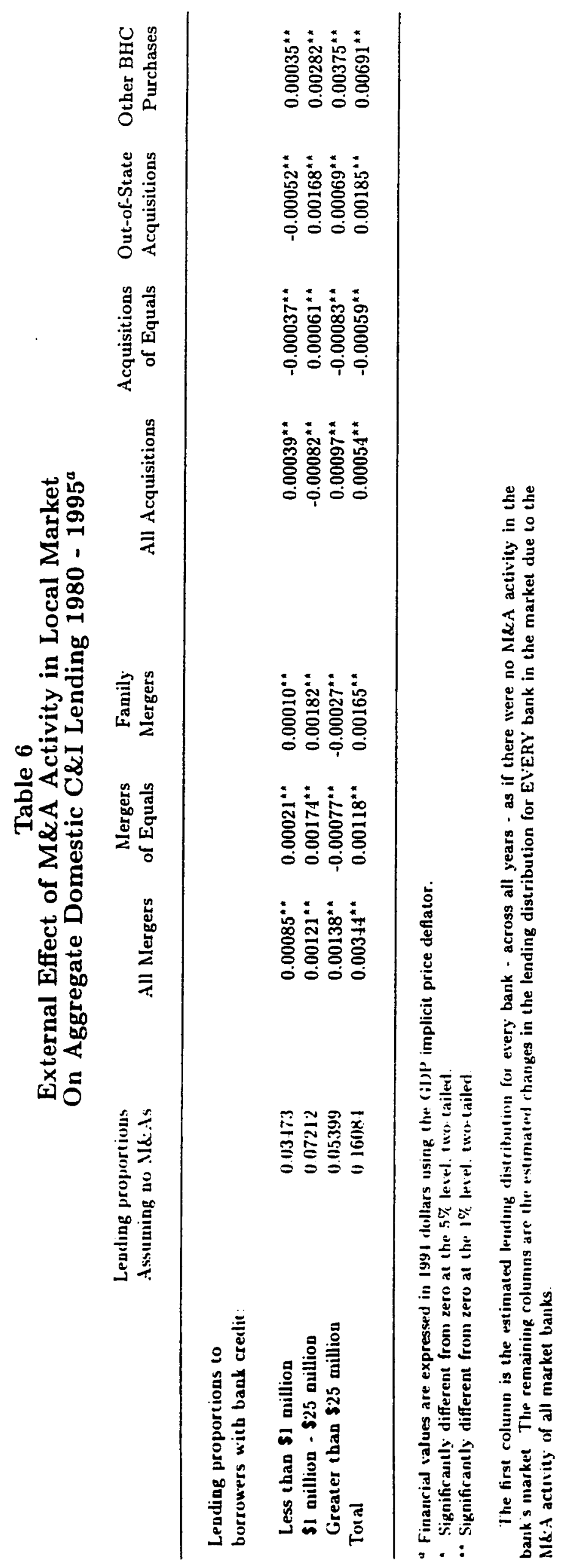




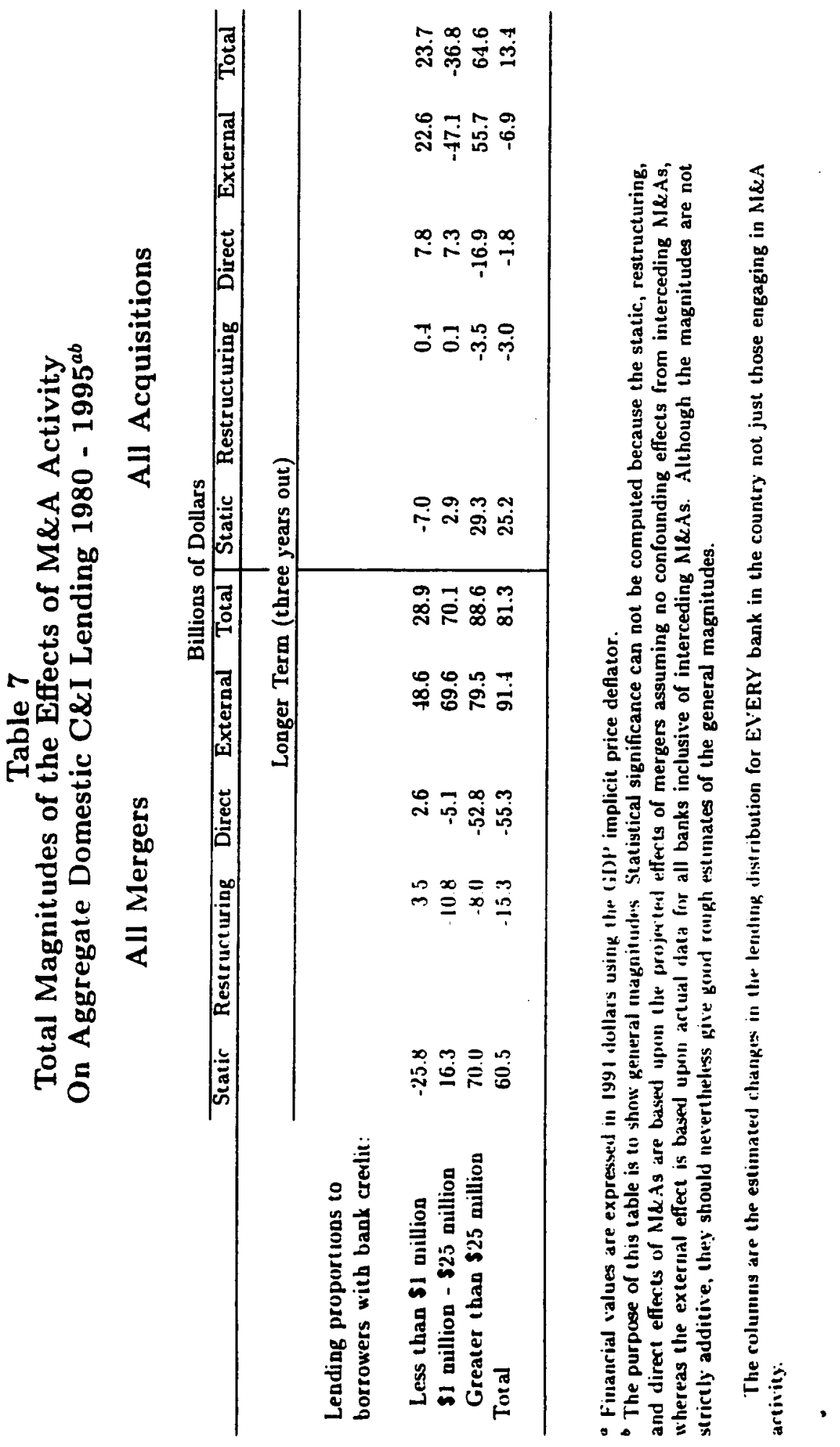




\section{Table A1}

\section{Grouped Logit Regressions of the Probability that a Dollar of GTA is Allocated to a Credit Availability Size Class}

\begin{tabular}{|c|c|c|c|c|c|c|}
\hline \multirow[b]{2}{*}{ Variable } & \multicolumn{2}{|c|}{$\begin{array}{c}\ln \left(P_{1} /\left(1-P_{1}\right)\right) \\
\text { Less than } \$ 1 \text { million }\end{array}$} & \multicolumn{2}{|c|}{$\begin{array}{c}\ln \left(P_{2} /\left(1-P_{2}\right)\right) \\
\$ 1 \text { nuillion }-\$ 25 \text { nillion }\end{array}$} & \multirow{2}{*}{\multicolumn{2}{|c|}{$\begin{array}{l}\ln \left(P_{3} /\left(1-P_{3}\right)\right) \\
\text { Greater than } \$ 25 \text { million }\end{array}$}} \\
\hline & Coefficient & t-Statistic & Coefficient & t-Statistic & & \\
\hline MEDBANK & $0.694^{*}$ & 2.12 & 0.103 & 0.16 & & \\
\hline LARBANK & $0.742^{*}$ & 2.01 & 0.299 & 0.45 & $-4.754^{* *}$ & -10.06 \\
\hline HUGBANK & 0.433 & 1.14 & 0.254 & 0.38 & $-4.443^{* *}$ & -8.95 \\
\hline LNGTA & -0.455 & -1.20 & 0.284 & 0.79 & $7.543^{2 *}$ & 7.73 \\
\hline $1 / 2(\text { LNGTA })^{2}$ & 0.001 & 0.06 & -0.030 & -1.37 & $-0.438^{* *}$ & -7.52 \\
\hline EQUITY/GTA & -3.191 & -0.35 & -5.983 & -1.50 & $26.037^{* *}$ & 4.01 \\
\hline $1 / 2(\mathrm{EQUITY} / \mathrm{GTA})^{2}$ & 14.045 & 0.12 & $85.559^{*}$ & 1.99 & -86.302 & -1.73 \\
\hline PFUNDS/GTA & -0.113 & -0.19 & $2.633^{\star \star \pi}$ & 6.54 & $4.054^{* *}$ & 4.47 \\
\hline $1 / 2$ (PFUNDS/GTA) ${ }^{2}$ & $-3.825 * *$ & -3.05 & $-5.219^{* *}$ & -6.43 & $-5.286^{\star \star}$ & -3.03 \\
\hline LLR/LOANS & -5.404 & -0.69 & -3.306 & -0.61 & $23.475^{\star}$ & 2.18 \\
\hline $1 / 2(\text { LLR/LOANS })^{2}$ & 78.694 & 0.37 & 160.460 & 1.09 & $-1087.936^{* *}$ & -3.49 \\
\hline OREO/LOANS & $-16.534^{* *}$ & -3.19 & $-7.055^{x}$ & -2.15 & 3.962 & 0.72 \\
\hline $1 / 2(\text { OREO/LOANS })^{2}$ & 170.887 & 1.34 & -133.592 & -1.38 & $512.381^{* *}$ & 3.23 \\
\hline NPI/LOANS & $-6.260^{*}$ & -2.30 & 0.057 & 0.03 & -0.041 & -0.01 \\
\hline $1 / 2(\mathrm{NPL} / \text { LOANS })^{2}$ & 61.114 & 1.81 & 0.222 & 0.01 & 8.626 & 0.24 \\
\hline MEDORG & 0.158 & 0.42 & -1.324 & -1.07 & & \\
\hline LARORG & 0.109 & 0.26 & -1.420 & -1.13 & $3.386^{* *}$ & 4.68 \\
\hline HUGORG & 0.283 & 0.65 & -1.419 & -1.13 & $3.313^{\star *}$ & 4.38 \\
\hline LNOGTA & 0.490 & 1.33 & $1.787^{* *}$ & 4.96 & $-3.048^{n *}$ & -3.08 \\
\hline $1 / 2(\text { LNOGTA })^{2}$ & -0.036 & -1.58 & $-0.110^{* *}$ & -5.11 & $0.186^{* *}$ & 3.22 \\
\hline ORG EQUITY/GTA & $-23.339^{\star}$ & -2.20 & $-13.086^{*}$ & -2.35 & $-91.461^{* *}$ & -9.98 \\
\hline 1/2(ORG EQUITY/GTA) $)^{2}$ & 234.863 & 1.63 & $246.627^{* *}$ & 3.41 & $966.972^{\star \bullet}$ & 8.09 \\
\hline ORG PFUNDS/GTA & 0.442 & 0.66 & 0.049 & 0.11 & $-5.577^{* *}$ & -5.91 \\
\hline 1/2(ORG PFUNDS/GTA) $)^{2}$ & -0.174 & -0.12 & -0.462 & -0.51 & $6.945^{* \prime}$ & 3.83 \\
\hline ORG LLR/LOANS & $-31.630^{* *}$ & -3.52 & -3.854 & -0.60 & -21.329 & -1.59 \\
\hline 1/2(ORG LLR/LOANS) ${ }^{2}$ & 461.616 & 1.85 & -112.956 & -0.64 & $1066.415^{\prime \prime \prime}$ & 2.78 \\
\hline ORG OREO/LOANS & 0.396 & 0.06 & $13.399^{n "}$ & 3.04 & -10.172 & -1.45 \\
\hline 1/2(ORG OREO/LOANS) $)^{2}$ & 28.769 & 0.19 & -153.154 & -1.05 & -73.686 & -0.26 \\
\hline ORG NPL/LOANS & $13.904^{* *}$ & 3.72 & 2.346 & 0.86 & 7.031 & 1.40 \\
\hline $1 / 2$ (ORG NPL/LOANS) $^{2}$ & -48.761 & -1.02 & -2.641 & -0.07 & $-145.517^{\star}$ & -2.32 \\
\hline IN BHC & $0.227^{n *}$ & 2.74 & $0.390^{* *}$ & 3.47 & 0.390 & 1.08 \\
\hline MULTIPLE LAYER BHC & $0.457^{* *}$ & 9.51 & -0.055 & -1.76 & 0.093 & 1.68 \\
\hline OUT OF STATE BHC & $-0.151^{*}$ & -2.47 & $0.297^{*}$ & 7.13 & $-0.276^{* *}$ & -3.26 \\
\hline REGISTER S.E.C. & $-0.220^{\circ}$ & -4.73 & $-0.109^{\star *}$ & -3.20 & $-0.360^{\circ}$ & -5.91 \\
\hline FED & $-0.186^{\prime \prime}$ & -4.70 & $-0.248^{\prime \prime}$ & -9.87 & $0.122^{* *}$ & 2.94 \\
\hline FDIC & $0.208^{\prime \prime}$ & 3.62 & $-0.186^{\circ "}$ & -3.28 & $1.376^{\circ "}$ & 9.61 \\
\hline IN MSA & $0.355^{\circ}$ & 3.29 & $0.621^{* *}$ & 3.46 & $1.772^{*}$ & 4.09 \\
\hline HERF & $1.031^{\circ}$ & 2.15 & -0.278 & -0.72 & $-5.258^{\circ}$ & -6.18 \\
\hline SHARE & 0.169 & 1.36 & 0.189 & 1.81 & $1.131^{\circ}$ & 2.39 \\
\hline ORG HERF & 0.052 & 0.09 & $-1.297^{\prime} \cdot$ & -2.72 & $5.841^{\circ}$ & 0.17 \\
\hline (IRG SHARE & 0.6013 & 1.50 & 0.070 & 0.23 & $-2.199 \%$ & -3.91 \\
\hline MRG 1 & $2.516^{\circ}$ & 2.92 & -1.11 .1 & -1.38 & $-1.619^{\circ}$ & -2.51 \\
\hline .MRG2 & -0.769 & -0.92 & $-2.552^{\circ}$ & -3.11 & $4.956^{\circ}$ & 2.92 \\
\hline .MRG3 & 0.70 .5 & 0.83 & 1.163 & 1.6 .1 & $-7.057^{*}$ & -1.08 \\
\hline IIRG1 L.NGTA & $-(1.165)^{\circ}$ & -3.03 & 0.078 & 1.57 & $0.287^{*}$ & 2.63 \\
\hline .MRG2 L.NGTA & 0.039 & 0.75 & $0.154^{\circ}$ & 3.10 & $-0.296^{\circ}$ & -2.92 \\
\hline MRG3 - LNGTA & -0.0 .18 & -0.90 & -0.066 & -1.53 & $0.415^{\circ}$ & 4.06 \\
\hline MRG EQ1 & -0.532 & -0.26 & $2.873^{\circ}$ & 2.0 .1 & -3.377 & -1.21 \\
\hline MRG EQ2 & 1.42()$^{\circ}$ & 2.13 & $2.211^{\circ}$ & 2.02 & $-6.061^{\circ} \cdot$ & -2.61 \\
\hline MRG EQ3 & $4.552^{\circ}$ & 2.96 & -0.680 & -0.70 & -4.004 & -1.87 \\
\hline MRG EQ1 - LNGTA & 0.038 & 0.30 & $-0.190^{\circ}$ & -2.22 & 0.179 & 1.08 \\
\hline MRG EQ2 - L.NGTA & $-0.288^{\circ}$ & .2 .5 .1 & $-0.130^{\circ}$ & -2.08 & $0.379^{\circ}$ & 2.79 \\
\hline MRG EQ3 - L.NGTA & $-10.312^{\circ}$ & .3 .22 & 0.1133 & 0.56 & $0.246^{\circ}$ & 1.97 \\
\hline MRG IN BHCI & - $4.5099^{\circ}$ & -3.67 & -0.239 & -0.25 & 2.123 & 1.02 \\
\hline MRG IN BHC'2 & $-3.2 .10^{\circ}$ & .2 .68 & 1.063 & 1.18 & $-6.691^{-1}$ & .3 .12 \\
\hline MRG IN BHC:3 & 1.0 .13 & 0.86 & -1.050 & -1.20 & $7.256^{\circ}$ & 3.80 \\
\hline
\end{tabular}




\begin{tabular}{|c|c|c|c|c|c|c|}
\hline \multirow[b]{2}{*}{ Variable } & \multicolumn{2}{|c|}{$\begin{array}{c}\ln \left(P_{1} /\left(1-P_{1}\right)\right) \\
\text { Less than } \$ 1 \text { million }\end{array}$} & \multicolumn{2}{|c|}{$\begin{array}{c}\ln \left(P_{2} /\left(1-P_{2}\right)\right) \\
\$ 1 \text { million - \$25 million }\end{array}$} & \multicolumn{2}{|c|}{$\begin{array}{l}\ln \left(P_{3} /\left(1-P_{3}\right)\right) \\
\text { Greater than } \$ 25 \text { million }\end{array}$} \\
\hline & Coefficient & & & t-Statistic & Coefficient & t-Statistic \\
\hline MRG IN BHCl $\cdot$ LNGTA & $0.301^{* *}$ & 3.84 & 0.017 & 0.29 & -0.157 & -1.28 \\
\hline MRG IN BHC2 - LNGTA & $0.228^{* \star}$ & 2.98 & -0.064 & -1.16 & $0.383^{* *}$ & 3.28 \\
\hline MRG IN BHC3 $\cdot$ LNGTA & -0.065 & -0.85 & 0.052 & 0.96 & $-0.428^{* *}$ & -3.89 \\
\hline$A C Q 1$ & -2.724 & -1.35 & -2.812 & -1.12 & -2.248 & -0.26 \\
\hline$A C Q 2$ & -2.646 & -1.48 & -1.450 & -0.88 & $13.990^{*}$ & 2.13 \\
\hline ACQ3 & -1.257 & -0.75 & -2.580 & -1.53 & $-22.261^{\star *}$ & -3.43 \\
\hline ACQ1 - INOGTA & 0.176 & 1.44 & 0.184 & 1.22 & 0.147 & 0.29 \\
\hline ACQ2 - LNOGTA & 0.164 & 1.49 & 0.120 & 1.21 & $-0.899^{*}$ & -2.37 \\
\hline ACQ3 - LNOGTA & 0.071 & 0.70 & 0.182 & 1.81 & $1.290^{* *}$ & 3.47 \\
\hline ACQ EQ1 & 0.510 & 0.22 & $6.543^{\circ}$ & 2.57 & -10.680 & -1.60 \\
\hline ACQ EQ2 & -0.792 & -0.38 & 1.773 & 0.92 & -7.671 & -1.47 \\
\hline ACQ EQ3 & -0.460 & -0.24 & 1.811 & 0.97 & 11.071 & 1.81 \\
\hline ACQ EQ1 - LNOGTA & -0.011 & -0.08 & $-0.418^{\star *}$ & -2.77 & 0.600 & 1.58 \\
\hline ACQ EQ2 - LNOGTA & 0.062 & 0.50 & -0.137 & -1.20 & 0.540 & 1.79 \\
\hline ACQ EQ3 - LNOGTA & 0.041 & 0.35 & -0.119 & -1.09 & -0.618 & -1.77 \\
\hline ACQ OUTSTATE1 & 3.619 & 1.34 & $-6.799^{\star}$ & -2.42 & 7.313 & 0.85 \\
\hline ACQ OUTSTATE2 & -0.796 & -0.34 & 1.896 & 0.97 & $-14.743^{*}$ & -2.38 \\
\hline ACQ OUTSTATE3 & $-5.227^{\star}$ & -2.37 & 0.559 & 0.31 & $18.194^{* *}$ & 2.82 \\
\hline ACQ OUTSTATE 1 - LNOGTA & -0.214 & -1.36 & $0.362^{*}$ & 2.18 & -0.469 & -0.91 \\
\hline ACQ OUTSTATE $2 \cdot$ LNOGTA & 0.047 & 0.34 & -0.143 & -1.24 & $0.875^{*}$ & 2.46 \\
\hline ACQ OUTSTATE3 - LNOGTA & $0.328^{*}$ & 2.53 & -0.073 & -0.70 & $-1.065^{* *}$ & -2.90 \\
\hline ORG ACQ1 & -0.752 & -1.44 & $-0.975^{\star}$ & -2.50 & $2.356^{* *}$ & 3.06 \\
\hline ORG ACQ2 & $1.598^{* *}$ & 2.92 & $1.568^{* *}$ & 3.88 & $-3.259^{* \star}$ & -3.82 \\
\hline ORG ACQ3 & 0.458 & 0.85 & 0.432 & 1.05 & -0.022 & -0.02 \\
\hline ORG ACQ1 - LNOGTA & 0.049 & 1.52 & $0.058^{*}$ & 2.52 & $-0.146^{* *}$ & -3.31 \\
\hline ORG ACQ2 - LNOGTA & $-0.102^{*}$ & -3.04 & $-0.094^{* *}$ & -3.93 & $0.190^{* *}$ & 3.87 \\
\hline ORG ACQ3 - LNOGTA & -0.029 & -0.89 & -0.028 & -1.16 & -0.008 & -0.16 \\
\hline MKT MRG1 & 0.330 & 0.19 & $4.896^{\prime \prime}$ & 2.79 & $-12.493^{\text {kn }}$ & -2.82 \\
\hline MKT MRG2 & $-7.284^{* 1}$ & -4.04 & 0.114 & .0 .06 & -1.855 & -0.41 \\
\hline MKT MRG3 & -2.060 & -1.17 & -2.184 & -1.28 & $12.309^{n} n$ & 3.01 \\
\hline MKT MRGI - LNGTA & -0.033 & -0.28 & $-0.323^{n *}$ & -2.98 & $0.724^{\wedge *}$ & 2.74 \\
\hline MKT MRG2 - LNGTA & $0.501^{\circ *}$ & 4.32 & 0.015 & 0.12 & 0.080 & 0.30 \\
\hline MKT MRG3 - LNGTA & 0.158 & 1.41 & 0.118 & 1.12 & $-0.721^{* *}$ & -2.95 \\
\hline MKT MRG EQI & -3.554 & -1.17 & $-7.061^{* \star}$ & -2.83 & $26.438^{* \star}$ & 5.14 \\
\hline MKT MRG EQ2 & 0.386 & 0.12 & -3.117 & -1.23 & $11.076^{*}$ & 2.06 \\
\hline MKT MRG EQ3 & $-7.801^{\star *}$ & -2.59 & 2.919 & 1.19 & $10.437^{*}$ & 1.96 \\
\hline MKT MRG EQ1 - LNGTA & 0.237 & 1.22 & $0.455^{\circ "}$ & 2.96 & $-1.509^{* *}$ & -4.89 \\
\hline MIKT MRG EQ2 - LNGTA & 0.023 & 0.11 & 0.225 & 1.45 & $-0.706^{*}$ & -2.20 \\
\hline MKT MRG EQ3 - LNGTA & $0.576^{*}$ & 2.98 & -0.125 & -0.83 & $-0.665^{*}$ & -2.09 \\
\hline MIRT MRG IN BHCI & 1.175 & 0.47 & -2.985 & -1.34 & $24.539 "$. & 4.75 \\
\hline MKT MRG IN BHC2 & $9683^{\circ}$ & 3.62 & $727.1^{\circ}$ & 3.15 & $12.472^{\circ}$ & 2.2 .5 \\
\hline MIKT MRG IN BHC3 & 2.980 & 1.06 & 0.921 & 0.10 & $-12.938^{\circ}$ & -2.51 \\
\hline MKT MRG IN BHCI LNGTA & -0.083 & $-(1.52$ & 0.201 & 1.16 & $-1.105^{\circ}$ & -1.55 \\
\hline MKT MRG IN BHC2 LNGTA & $-\left(1.684^{\cdots}\right.$ & .3 .93 & $-\left(1.479^{\circ}\right.$ & -3.33 & $-0.693^{\circ}$ & -2.08 \\
\hline MKT MRG IN BIIC3 - L.NGTA & -0.2012 & -1.11 & -0.0007 & -0.05 & $0.756^{\circ}$ & 2.1 .1 \\
\hline .MKT ACQI & -6.149 & -1.52 & 6.371 & 1.10 & 27.705 & 1.60 \\
\hline MKT ACQ2 & 0.0 .17 & 0.01 & 3.798 & 0.83 & $-.17 .197^{\circ}$ & -2.92 \\
\hline IIKT ACQ3 & 2.120 & 11.5 .5 & 3.7 .17 & 0.83 & 7.881 & 0.55 \\
\hline .IKT ACQ1 - LNOGTA & 0.380 & 1.17 & -0.399 & -1.14 & -1.711 & -1.70 \\
\hline MIKT ACQ2 - LNOGTA & -0.016 & -0.06 & -0.267 & -0.98 & $2.795 *$ & 2.97 \\
\hline MKT ACQ3 - LNOGTA & .0 .060 & -0.25 & -0.318 & -1.19 & -0.111 & $-0.5 n$ \\
\hline MKT ACQ EQ1 & $10.212^{\circ}$ & 2.0 .4 & -.1 .1 .15 & -0.79 & 5.153 & $\mathbf{0 . 3 . 1}$ \\
\hline MKT ACQ EQ2 & $\mathbf{9 . 4 3 0}$ & 1.86 & .7 .855 & -1.44 & $58.272^{* *}$ & 3.11 \\
\hline MKT ACQ EQ3 & 1.146 & 0.27 & 4.0.45 & 0.87 & -5.692 & -0.43 \\
\hline MKT ACQ EQ1 - L.VOGTA & $-0.649^{\circ}$ & -2.10 & 0.238 & 0.76 & -0.170 & -0.19 \\
\hline .UKT ACQ EQ2 - LNOGTA & -0.580 & -1.87 & 0.502 & 1.57 & $-3.472^{\circ}$ & -3.25 \\
\hline MKT ACQ EQ3 - LNOGTA & -0.160 & .0 .61 & -0.200 & -0.75 & 0.20 .4 & 0.27 \\
\hline
\end{tabular}


(continued from previous page)

\begin{tabular}{|c|c|c|c|c|c|c|}
\hline \multirow[b]{2}{*}{ Variable } & \multicolumn{2}{|c|}{$\begin{array}{l}\quad \ln \left(P_{1} /\left(1-P_{1}\right)\right) \\
\text { Less than } \$ 1 \text { million }\end{array}$} & \multicolumn{2}{|c|}{$\begin{array}{c}\ln \left(P_{2} /\left(1-P_{2}\right)\right) \\
\$ 1 \text { million }-\$ 25 \text { million }\end{array}$} & \multicolumn{2}{|c|}{$\begin{array}{c}\ln \left(P_{3} /\left(1-P_{3}\right)\right) \\
\text { Greater than } \$ 25 \text { million }\end{array}$} \\
\hline & Coefficient & $\mathrm{t}$-Statistic & Coefficient & $\mathrm{t}$-Statistic & Coefficient & t-Statistic \\
\hline MKT ACQ OUTSTATEI & 4.626 & 0.98 & 6.296 & 1.25 & $-45.340^{\star \star}$ & -2.63 \\
\hline MIKT ACQ OUTSTATE2 & 7.832 & 1.65 & -0.378 & -0.07 & 32.534 & 1.86 \\
\hline MKT ACQ OUTSTATE3 & 2.318 & 0.53 & $-16.932^{* \prime}$ & -3.48 & 10.233 & 0.72 \\
\hline MKT ACQ OU்TSTATEI · LNOGTA & -0.285 & -0.97 & -0.366 & -1.21 & $2.659^{\star \star}$ & 2.65 \\
\hline MKT ACQ OUTSTATE2 - LNOGTA & -0.508 & -1.71 & 0.068 & 0.23 & -1.797 & -1.78 \\
\hline MKT ACQ OUTSTATE3 - LNOGTA & -0.237 & -0.87 & $1.098^{* *}$ & 3.84 & -0.525 & -0.64 \\
\hline MKT ORG ACQ1 & $3.360^{21}$ & 3.30 & $3.188^{* \prime}$ & 3.46 & $-9.218^{* \star}$ & -4.43 \\
\hline MKT ORG ACQ2 & -0.043 & -0.04 & 0.034 & 0.04 & $6.218^{\mathrm{nt}}$ & 3.16 \\
\hline MKT ORG ACQ3 & -1.270 & -1.22 & -0.492 & -0.53 & $8.573^{\star *}$ & 4.07 \\
\hline MKT ORG ACQI - LNOGTA & $-0.204^{* *}$ & -3.25 & $-0.192^{* *}$ & -3.54 & $0.534^{*}$ & 4.43 \\
\hline MKT ORG ACQ2 - LNOGTA & 0.005 & 0.07 & 0.001 & 0.02 & $-0.345^{\prime \prime}$ & -3.01 \\
\hline MKT ORG ACQ3 - LNOGTA & 0.089 & 1.39 & 0.044 & 0.79 & $-0.484^{\star n}$ & -3.96 \\
\hline QYEAR80 & 1.308 & 0.66 & $-16.588^{n=}$ & -7.09 & $-40.952^{* *}$ & -6.38 \\
\hline QYEAR81 & 1.198 & 0.60 & $-16.672^{n *}$ & -7.12 & $-40.842^{* \prime}$ & -6.36 \\
\hline QYEAR82 & 0.958 & 0.48 & $-16.691^{\star x}$ & -7.13 & $-40.643^{* *}$ & -6.33 \\
\hline QYEAR83 & 0.723 & 0.36 & $-16.855^{n " *}$ & -7.20 & $-40.301 *$ & -6.28 \\
\hline QYEAR84 & 0.661 & 0.33 & $-16.731^{* *}$ & -7.15 & $-40.466^{n *}$ & -6.30 \\
\hline QYEAR85 & 0.148 & 0.07 & $-17.004^{* *}$ & -7.26 & $-40.383^{* x}$ & -6.30 \\
\hline QYEAR86 & 0.216 & 0.11 & $-16.862^{* *}$ & -7.20 & $-40.597^{* \prime \prime}$ & -6.34 \\
\hline QYEAR87 & 0.139 & 0.07 & $-16.946^{\star \star *}$ & -7.24 & $-40.342^{* n}$ & -6.30 \\
\hline QYEAR88 & 0.316 & 0.16 & $-16.761 * *$ & -7.16 & $-40.603^{* *}$ & -6.34 \\
\hline QYEAR89 & 0.345 & 0.17 & $-16.703^{* *}$ & -7.13 & $-40.586^{* *}$ & -6.33 \\
\hline QYEAR90 & 0.386 & 0.19 & $-16.577^{* *}$ & -7.08 & $-40.798^{* *}$ & -6.36 \\
\hline QYEAR91 & 0.242 & 0.12 & $-16.736^{* *}$ & -7.14 & $-40.631^{* *}$ & -6.33 \\
\hline QYEAR92 & 0.107 & 0.05 & $-16.667^{* *}$ & -7.11 & $-40.804^{* \prime}$ & -6.36 \\
\hline QYEAR93 & 0.242 & 0.12 & $-16.609^{*}$ & -7.09 & $-40.964^{\star \prime \prime}$ & -6.38 \\
\hline QYEAR94 & 0.369 & 0.19 & $-16.712^{* *}$ & -7.13 & $-40.966^{\prime \prime}$ & -6.38 \\
\hline QYEAR95 & 0.249 & 0.13 & $-16.524^{n *}$ & -7.05 & $-40.712^{* *}$ & -6.34 \\
\hline $\mathrm{AL}$ & $0.471^{\circ !}$ & 4.00 & -0.080 & -0.71 & -0.079 & -0.28 \\
\hline AK & -0.170 & -0.37 & -0.391 & -0.75 & -3.653 & -0.65 \\
\hline $\mathrm{AZ}$ & -0.104 & -0.78 & 0.033 & 0.25 & -0.331 & -1.09 \\
\hline $\mathrm{AR}$ & $-1.080^{* *}$ & -2.91 & 0.561 & 1.14 & -2.005 & -0.32 \\
\hline $\mathrm{CO}$ & -0.154 & -1.15 & -0.010 & -0.09 & 0.271 & 0.54 \\
\hline $\mathrm{CT}$ & $-0.706^{x "}$ & -3.70 & $1.054^{* *}$ & 5.29 & $1.871^{\circ}$ & 3.74 \\
\hline$D E$ & -0.307 & -1.18 & -0.120 & -0.56 & -0.064 & -0.22 \\
\hline $\mathrm{DC}$ & $-0.670^{n "}$ & -4.40 & $-0.528^{n "}$ & -4.84 & -0.059 & -0.26 \\
\hline FL & $-0.790^{\prime \prime}$ & -3.64 & $-1.087^{* *}$ & -4.87 & 0.263 & 0.86 \\
\hline GA & -0.169 & -1.22 & $0.577^{\prime \prime}$ & 6.19 & -0.307 & -1.69 \\
\hline $\mathrm{HI}$ & $-0.420^{\prime \prime}$ & -2.60 & 0.148 & 0.92 & -0.606 & -1.52 \\
\hline ID & 0.330 & 1.38 & -0.545 & -1.24 & 2.591 & 1.02 \\
\hline IL & 0.032 & 0.35 & $0.279^{\circ}$ & 1.51 & $0.671^{n}$ & 6.8 .5 \\
\hline I. & -0.228 & -1.85 & -0.2012 & -1.72 & $-1.070^{\circ}$ & -2.47 \\
\hline $1 A$ & -0.229 & -0.90 & -0.2 .17 & -0.53 & -1.196 & -0.08 \\
\hline $\mathrm{KS}$ & -11.371 & -1.08 & 1.350 & $1.2 \cdot 1$ & 2.969 & 0.56 \\
\hline $\mathrm{KY}$ & -0.11 .1 & -01.95 & $0.2933^{-\cdot}$ & 3.22 & -0.126 & -0.57 \\
\hline LA & $0.36 .1^{\circ}$ & 3.10 & 0.136 & 1.24 & 1.457 & $1.90)$ \\
\hline$M E$ & -01.398 & -1.1 .3 & -0.22 .3 & -0.61 & -0.977 & -0.07 \\
\hline$M D$ & -0.205 & -1.93 & -0.131 & -166 & $-0.1 .11^{\circ}$ & -2.57 \\
\hline$M A$ & -0.1 .12 & -1.50 & $0.06 i$ & 108 & $0.691^{\cdots}$ & $0.9 n$ \\
\hline.$M I$ & $0.275^{\circ}$ & 3.03 & 0.122 & 1.78 & $0.507^{-\cdot .}$ & 1.15 \\
\hline$M N$ & -0.211 & -1.63 & $0.206^{\circ}$ & 3.63 & $0.520^{\circ}$ & 3.17 \\
\hline MS & $-0.722 \%$ & -3.06 & -0022 & .0 .11 & -0.032 & -0.0 .1 \\
\hline MO & $-0.376^{\prime \prime}$ & -3.12 & $-0.299^{\circ}$ & -3.40 & 0.206 & 1.05 \\
\hline MT & $-0.18 \cdot 1$ & -0.39 & 0.895 & 0.36 & -7.095 & -0.01 \\
\hline$N E$ & $-0.708^{\circ}$ & -2.31 & -0.140 & -1.24 & -6.332 & -0.12 \\
\hline $\mathrm{NV}$ & -0.0 .13 & -0.21 & 0.055 & 0.25 & -5.10 .1 & $-(1) .60$ \\
\hline $\mathrm{NHI}$ & -0.095 & -0.31 & -0.327 & -0.96 & -11.731 & -0.22 \\
\hline N.J & $0.314^{\circ}$ & 2.96 & 0.111 & 1.25 & $-0.623^{\circ}$ & -2.38 \\
\hline$\therefore M$ & 0.388 & 0.92 & 0.43 .1 & 0.41 & -3.429 & -0.13 \\
\hline$N Y^{\circ}$ & $-0.210^{\circ}$ & -3.05 & $0.127^{*}$ & 2.71 & $0.188^{\circ}$ & 2.12 \\
\hline $\mathrm{xC}$ & $-0.221^{\circ}$ & -2.31 & $0.170^{\circ}$ & 2.38 & 0.180 & 1.31 \\
\hline
\end{tabular}

(contiuural ou uext page) 
(continued from previous page)

\begin{tabular}{|c|c|c|c|c|c|c|}
\hline \multirow[b]{2}{*}{ Variable } & \multicolumn{2}{|c|}{$\begin{array}{l}\ln \left(P_{1} /\left(1-P_{1}\right)\right) \\
\text { Less than } \$ 1 \text { million }\end{array}$} & \multicolumn{2}{|c|}{$\begin{array}{c}\ln \left(P_{2} /\left(1-P_{2}\right)\right) \\
\$ 1 \text { million }-\$ 25 \text { million }\end{array}$} & \multirow{2}{*}{\multicolumn{2}{|c|}{$\begin{array}{c}\ln \left(P_{3} /\left(1-P_{3}\right)\right) \\
\text { Greater than } \$ 25 \text { nillion }\end{array}$}} \\
\hline & Coefficient & t-Statistic & Coefficient & t-Statistic & & t-Statistic \\
\hline ND & -1.887 & -0.68 & -11.365 & -0.01 & & \\
\hline $\mathrm{OH}$ & $-0.205^{*}$ & -2.33 & 0.011 & 0.17 & 0.170 & 1.29 \\
\hline OK & -0.141 & -1.01 & -0.075 & -0.64 & 0.513 & 1.07 \\
\hline OR & -0.179 & -1.54 & -0.029 & -0.32 & $0.696^{* *}$ & 3.93 \\
\hline PA & $-0.264^{* *}$ & -3.22 & $0.267^{*=}$ & 4.58 & $0.500^{n *}$ & 4.89 \\
\hline RI & $-1.225^{* x}$ & -7.84 & $0.427^{\star *}$ & 4.82 & $-0.490^{*}$ & -2.30 \\
\hline $\mathrm{SC}$ & -0.171 & -0.35 & 0.187 & 0.23 & -1.246 & -0.03 \\
\hline SD & -0.572 & -1.12 & 0.048 & 0.08 & -12.690 & -0.05 \\
\hline TN & -0.174 & -1.59 & 0.110 & 1.30 & $0.759^{* \prime "}$ & 2.83 \\
\hline$T X$ & -0.131 & -1.46 & $0.214^{n=}$ & 3.32 & $0.931^{* *}$ & 8.02 \\
\hline UT & 0.314 & 1.41 & $-0.619^{*}$ & -2.01 & 0.141 & 0.11 \\
\hline VT & -0.401 & -1.25 & 0.221 & 0.42 & 1.542 & 0.12 \\
\hline VA & $-0.871^{* *}$ & -6.04 & $-0.348^{* *}$ & -3.54 & $0.526^{\star *}$ & 3.14 \\
\hline WA & $0.336^{* *}$ & 3.57 & 0.091 & 1.05 & $0.654^{* *}$ & 3.00 \\
\hline WV & -0.968 & -0.81 & -12.341 & -0.03 & -9.801 & 0.00 \\
\hline WI & -0.036 & -0.30 & 0.173 & 1.81 & $-0.883^{* \star}$ & -3.05 \\
\hline WY & 0.036 & 0.12 & -1.196 & -1.21 & 2.484 & 0.24 \\
\hline$N$ & 4,5 & & & & & \\
\hline Adjusted $\mathrm{R}^{2}$ & 0.5 & & & & & \\
\hline
\end{tabular}

- Indicates significance at the $5 \%$ level.

** Indicates significance at the $1 \%$ level.

Note: In the vast majority of cases, we have the exact total of domestic Ci\&I lending for each bank, but the exact distribution among the three rlasses of borrowers needs to be estimated using STBL data. In order for these estimates to sum to the actual total, we multiply them by an adjustment factor, which is tqual to the ratio of the bank's actual total c\&il lending to the sum of the predicted lending from the STBL-based model. In the few cases where we do not have the exact value of a bank's total C\&l lending, we use the average adjustment factor for the bank's size class for the specified year. 